\title{
Causation, Valuation, and Chance in Personal Injury Torts Involving Preexisting Conditions and Future
} Consequences

\author{
Joseph H. King, Jr.†
}

It has been observed that sooner or later most of those who are interested in the law of torts turn their attention explicitly to the subject of causation. ${ }^{1}$ Unfortunately, all too often examination of causation is not accompanied by analysis of its companion concept of "valuation," the process of identifying and assessing the value of the interest destroyed. ${ }^{2}$ Even when valuation is considered with causation, understanding often is inhibited by a tendency to commingle the concepts. Nowhere are these analytical shortcomings more harshly manifested nor is there more need of reasoned rectification than in the contexts of personal injuries involving victims suffering from preexisting conditions and of claims for future consequences of an injury.

Causation refers to the cause and effect relationship that must be established between tortious conduct and a loss before liability for that loss may be imposed. ${ }^{3}$ Causation questions relate to the fact of a loss or of its

† Professor of Law, University of Tennessee College of Law. The author wishes to express his appreciation to Ms. Susan Herndon for her editorial assistance on an earlier draft of this article.

1. Calabresi, Concerning Cause and the Law of Torts: An Essay for Harry Kalven, Jr., 43 U. CHI. L. REV. 69, 69 (1975).

2. There are two interrelated functions that are served by the causation and valuation processes. First, the rules may satisfy a perception of what fundamental considerations of justice require. In this sense, the requirement of causation seems to fulfill a basic sense of symmetry in the ordering of human affairs. Redress for losses "caused" seems to return the scales to equipoise. By performing this function, causation and valuation may enhance respect for the legal system and the rule of law.

The second role of causation and valuation is to contribute to an optimal allocation of resources. Rules of causation and valuation determine when a particular loss will be assigned to a specific individual or entity. This loss-assigning function helps assure that consumers are informed of the "real" costs of the many products, services, and activities that may cause accidental injuries, and also animates the deterrent, incentive, and loss-distributing goals of tort law. The fundamental rationale of enterprise liability - that the cost of accidents caused by an enterprise should be charged to the enterprise as a cost of doing business-is effectuated by the concepts of causation and valuation. See generally Klemme, The Enterprise Liability Theory of Torts, 47 U. COLO. L. REV. 153 (1976). Society's resources will be more likely to be allocated optimally if consumers can weigh true costs.

3. For a general discussion of the cause-in-fact requirement in tort law, see A. BECHT \& F. Miller, THE TEST OF FACTUAL CAUSATION (1961), F. HARPER \& F. JAMES, THE LAW OF TORTS $\$$ 20.2 (1956 \& Supp. 1968), H. HART \& A. HONORE, CAUSATION IN THE LAW 103-229 (1959), and W. Prosser, HANDBOOK OF THE LAW OF TORTS §§ 4l-45 (4th ed. 1971). 
source. Valuation is the process of identifying and measuring the loss that was caused by the tortious conduct. Although these concepts serve similar goals, they are different. An appreciation of this difference is a first step in dealing rationally with problems of preexisting conditions and future consequences in tort cases.

Under a tort system of accident compensation, individualized recoveries are awarded in an effort to make whole each particular plaintiff. In such a compensation system, preexisting conditions are unavoidable realities that must enter into the valuation-damages calculus. Every victim of tortious conduct inevitably brings to the transaction a tangle of preexisting conditions. These conditions may already have produced or preordained part or all of the harm for which the plaintiff seeks redress. The courts face the increasingly difficult tasks of sorting out the various preexisting conditions and tortious acts that may affect the value of a particular interest, and of allocating responsibility among them. Assessment of damages is further complicated by the fact that the value of an interest may depend significantly upon future expectancies of gain and health, with damages in turn depending on the extent to which a tortious injury affects those expectancies.

The response of the courts to questions of causation and valuation involving preexisting conditions and claims for future consequences has been largely unsatisfactory. Their failure to distinguish between the functions of causation and valuation, or to identify and value rationally the true interests lost, has created a serious gap in the remedial structure. Courts have had difficulty perceiving that a chance of avoiding some adverse result or of achieving some favorable result is a compensable interest in its own right. In some respects the notion of chance has been subsumed into the final result. When this occurs, the loss of a chance of avoiding some adverse result or achieving some favorable result either is completely redressed or is denied, depending on the likelihood, destroyed by the defendant's tortious conduct, of avoiding or achieving the particular result.

It is the thesis of this article that the loss of a chance of achieving a favorable outcome or of avoiding an adverse consequence should be compensable and should be valued appropriately, rather than treated as an all-or-nothing proposition. Preexisting conditions must, of course, be taken into account in valuing the interest destroyed. When those preexisting conditions have not absolutely preordained an adverse outcome, however, the chance of avoiding it should be appropriately compensated even if that chance is not better than even.

This article begins by attempting to create a rational analytic framework within which questions of preexisting conditions and damages for future consequences can be addressed and resolved. Part I attempts to elu- 
cidate the distinction between the causation and valuation inquiries and to develop a workable definition of preexisting conditions. Part II examines the ways in which the courts have traditionally dealt with the problem of preexisting conditions, future consequences, and loss of a chance in personal injury cases. Finally, the article proposes a more consistent and rational approach to the loss of a chance in personal injury law and suggests a method of valuing chance. ${ }^{4}$

\section{Distinguishing Matters of Causation and Valuation}

It is not uncommon for courts to apply the concept of causation to matters of valuation as well as causation. This melding of concepts is more than a matter of style or nomenclature; it has often affected the ways courts deal with preexisting conditions and future consequences. Therefore, in a careful analysis of the problem of preexisting conditions and future consequences, the notions of causation and valuation must be distinguished. $^{5}$

\section{A. The Nature of Causation in Tort Law}

Proof that a defendant engaged in tortious conduct will not alone render him civilly liable. The other elements of a valid cause of action must be established, ${ }^{6}$ and one of these elements is causation. ${ }^{7}$ While a defendant's conduct need not be and indeed never could be the sole cause of the injury, it must at least have been a cause of the loss claimed.

The traditional test of causation is the "but for" or "sine qua non" test." Under this test, causation exists when the injury would not have occurred "but for" the defendant's tortious conduct. In recent years, due to the influence of the late Dean Prosser and the Restatements of Torts, the

4. A number of these matters were addressed in an earlier work in a fairly specific factual context. See J. KiNG, The LAW OF MEdiCAL MALPRACTICE IN A NUTSHELL 196-204 (1977). The proposal there that the loss of a chance be included in determining the extent of a tortfeasor's liability is reexplored and extensively claborated upon here.

5. Articulation of the difference between causation and valuation has been attempted by a number of commentators. See, e.g., A. BECHT \& F. MILLER, supra note 3, at 123-30; W. PROSSER, supra note 3, $\S 52$, at 321-22; Malone, Ruminations on Cause-In-Fact, 9 STAN. L. REV. 60, 80-81 (1956).

6. See W. PROSSER, supra note $3, \S 30$ (discussing clements of cause of action for negligence). The elements of different torts tend to vary with the particular tort involved, but causation is a universal element. Id. $\S 41$, at 236 .

7. Id. Causation (or cause in fact) is a very different concept from that of "proximate cause." Causation refers to the cause and effect relationship between the tortious conduct and the injury. The doctrine of proximate cause encompasses the whole panoply of rules that may deny liability for otherwise actionable causes of harm. See generally R. KEETON, LEGAL CAUSE IN THE LAW OF TORTS (1963); W. PROSSER, supra note 3, §§ 41-45.

8. See, e.g., Polyard v. Terry, 160 N.J. Super. 497, 510-12, 390 A.2d 653, 660-61 (1978), affd per curiam, 79 N.J. 547, 401 A.2d 532 (1979); Schenck v. Roger Williams Gen. Hosp., 382 A.2d 514, 516-17 (R.I. 1977). See generally A. BECHT \& F. MLLLER, supra note 3, at 13-21; H. HART \& A. HONORE, supra note 3, at 103-22. 
"substantial factor" test has been advocated as a replacement for the butfor test. ${ }^{9} \mathrm{~A}$ force or condition is deemed a cause of a victim's harm when it was a "substantial factor" in bringing that result about. ${ }^{10}$ The substantial factor test retains but-for causation as an essential precondition ${ }^{11}$ except in situations in which two or more actively operating forces, for only one of which the defendant was responsible, combine to bring about the harm, and each alone would have been sufficient to bring about the harm. ${ }^{12}$

The causation inquiry has traditionally had an all-or-nothing effect on the outcome of a tort claim. Unless a causal connection is established under the applicable standard of proof (usually requiring that it appear more likely than not), the plaintiff will receive nothing for the loss in question. ${ }^{13}$

\section{B. Valuation and the Nature of Preexisting Conditions}

Valuation is animated by a premise similar to that underlying causation: that a tortfeasor should be charged only with the value of the interest he destroyed. In determining what that value is, the preinjury condition of the victim should be taken into account. Valuation therefore requires that there be a workable definition of preexisting conditions-those conditions that should be considered in assessing the value of the interest destroyed.

There are always forces and conditions other than the defendant's conduct that must be considered in valuing an interest. Some of these forces will constitute contributing causes of the injury, some will constitute preexisting conditions, and some will constitute both preexisting conditions and contributing causes.

In some situations, another force or condition will constitute a contrib-

9. See RESTATEMENT (SECOND) OF TORTS $\$ \S 431-433$ (1965); W. PROSSER, supra note 3, $\$ 41$, at 239-41. The substantial factor rule is expressly adopted and articulated in the contexts of negligence, intentional torts, and strict liability. See RESTATEMENT (SECOND) OF TORTS $§ 431$, Comment e (1965). The most recent part of the Restatement also explicitly adopts the foregoing principles for intentional torts. See RESTATEMENT (SECOND) OF TORTS $\$ 870$, Comment $l$ (1979). Other sections of the 1965 part of the Restatement, however, clouded the issue by seeming to suggest a more lenient test of causation for cases involving intentional or reckless conduct. See RESTATEMENT (SECOND) OF TORTS $\S$ 433, Comment c (1965); id. $\S 501(2)$.

10. RESTATEMENT (SECOND) OF TORTS $\$ 431$ (1965).

11. See id. $\$ 432(1)$.

12. Id. $\S 432(2)$. The classic example is that of two fires, one set by the defendant and one of other origin, that converge before destroying the plaintiffs property and causing personal injury, and either one of which would have been sufficient to do the harm. Id. (illustration 3). In one sense, the but-for ingredient is not completely dispensed with even in this situation. It must still appear that in the absence of the other actively operating forces, the harm would not have occurred but for the defendant's tortious conduct. For further analysis of the substantial factor test, see p. 1360 \& note 26 infra.

13. See, c.g., RESTATEMENT (SECOND) OF TORTS \& 433B \& Comment a (1965). For a rare instance of a departure from the all-or-nothing approach to causation, see Sindell v. Abbott Laboratories, 26 Cal. 3d 588, 607 P.2d 924, 163 Cal. Reptr. 132, cert. denied, 101 S. Ct. 286 (1980) (discussed in note 116 infra). 
uting cause of the injury, but not a preexisting condition. That some other force is a contributing cause does not necessarily prevent the defendant's conduct from being a cause. ${ }^{14}$ One can imagine numerous examples of multiple contributing causes of an injury. Assume that a physician negligently prescribes a medication in a dose that is obviously excessive. Thereafter, a nurse administers the drug without seeking confirmation or otherwise questioning the dosage level. The conduct of both would be contributing causes of the injury. The doctor's negligence is not a preexisting condition.

Generally, a preexisting condition may be defined as a disease, condition, or force that has become sufficiently associated with the victim to be factored into the value of the interest destroyed, and that has become so before the defendant's conduct has reached a similar stage. ${ }^{15} \mathrm{~A}$ threatening force or condition should qualify when it has "attached" - that is, its association with the value of the interest in question could not be avoided even if the victim were aware of its existence-and has attached before the defendant's conduct has reached a similar stage. Such conditions and forces should ordinarily be taken into account in determining the value of the interest lost.

This definition can be illustrated by the case of Dillon v. Twin State Gas \& Electric Co. ${ }^{16}$ A youth lost his balance and started to fall from a bridge, but before he was completely off the bridge, he came into contact with the defendant's high tension wires and was electrocuted. The electrical charge threw the youth back onto the bridge and therefore it could not be known whether he could have regained his balance had he not been electrocuted. The plaintiff sued the electric company for negligence in not insulating the charged accessible wires. The New Hampshire Supreme Court correctly held that although the electrical current "caused" the death regardless of the fall, the fact that the victim had lost his balance and had started to fall should be taken into account in assessing the extent of the defendant's liability. ${ }^{17}$ Damages would therefore depend in part on the victim's prospects of either regaining his balance or surviving the fall prior to being electrocuted. ${ }^{18}$ At the time of the electrocution the fall was

14. In this connection, the Restatement states:

In order that a negligent actor may be liable for harm resulting to another from his conduct, it is only necessary that it be a legal cause of the harm. It is not necessary that it be the cause, using the word 'the' as meaning the sole and even the predominant cause.

RESTATEMENT (SECOND) OF TORTS $\$ 430$, Comment d (1965).

15. See W. Prosser, supra note $3, \S 52$, at $32 \mathrm{l}-22$.

16. 85 N.H. 449,163 A. 111 (1932).

17. Id. at $456-57,163$ A. at $114-15$.

18. The Dillon court correctly understood when a force should be deemed a preexisting condition, but it (like most courts), by adopting an all-or-nothing approach to chance in the context presented, misperceived the appropriate way of taking preexisting conditions into account for valuation purposes. 
already in progress. It had attached, and at least its onset could not have been averted. Perhaps the youth could have regained his balance; perhaps he could not. But the beginning of the fall-the loss of balance and resulting loss of physical support-was an accomplished fact, and thus a preexisting condition.

Consider another example. Assume that the decedent was negligently killed as he was about to board the Titanic. Under the proposed test, the fact that an iceberg was growing in the North Atlantic and was apparently destined to sink the ship would not be a preexisting condition to be considered in assessing the value of the decedent's life. Although the growing iceberg was a threatening force, it was an avoidable one if, under the proposed definition, one assumes prescience. Some commentators who have considered the "doomed steamer" example have found, on a more visceral level, that the threat to the ship was simply too remote and contingent to be introduced into the interest-loss valuation. ${ }^{19}$ The retrospective conjuring up of events contingent at the time of injury would open the door to absurd results. Allowing such contingencies to affect valuation would create a rule that could not be administered. The proposed definition affords an appropriate and predictable selection mechanism for identifying preexisting conditions.

A condition or force also may operate as a contributing cause of an injury in one respect and as a preexisting condition in another. A doctor may, for example, negligently fail to diagnose a preexisting disease, allowing it to progress, with harmful effects. The disease was obviously a cause of the harm. The doctor's negligence in allowing the disease to progress may also have caused harm. In assessing the value of that loss, the disease should be deemed a preexisting condition and be taken into account.

Whether a force or condition should be deemed a contributing cause, a preexisting condition, or in some respects both can be a difficult question. Perhaps the simplest way to address the problem is to inquire initially whether a force or condition should be treated as a preexisting condition.

19. Prosser seems to have opted for this visceral approach, stating that "if such factors as these are to be considered as reducing value, they must be in operation when the defendant causes harm, and so imminent that reasonable men would take them into account." W. PROSSER, supra note $3, \S 52$, at 321 (emphasis added). Justice Peaslee, who first invoked the "doomed steamship" example, observed that the reasons for not finding a preexisting condition were "more readily felt than stated." Peaslee, Multiple Causation and Damage, 47 HARV. L. REV. 1127, 1140 (1934). Peaslee would also judge value by "known portents" and disregard unsuspected future events. Id. This approach differs from the test proposed in the text, which would weigh future threats, including unknown ones, as long as they had in fact "attached"-that is, become unavoidable-at the time of injury. While the proposed test and Peaslee's test would reach the same result in the Titanic case, they would reach different results in other situations. In those instances, the proposed test is preferable since it more accurately reflects the actual status of the affected interest at the time of the injury. 
When a preexisting condition is also a contributing cause, that fact should ordinarily not prevent the condition from affecting the amount of damages that the plaintiff receives.

Matters may be complicated when two forces, a preexisting force and the defendant's tort, actively operate within a short time span to cause or contribute to some end result that does not appear readily divisible. The defendant's conduct generally will not have been a cause of the entire harm, because the effect of the preexisting force almost always will have reduced the value of the interest that the defendant destroyed. Some courts, failing to distinguish between the two ideas, have held that because the result does not appear readily divisible, the harm is incapable of apportionment as a matter of law, and have held the defendants jointly and severally liable for the entire harm suffered. ${ }^{20}$ If both of two forces are causes of the entire harm (so that neither is a preexisting condition) and there is therefore no reasonable causal basis for apportioning the harm, joint and several liability for the entire harm may be appropriate. ${ }^{21}$ Even when another force is a preexisting condition and the defendant's tort is therefore not a cause of the entire harm, it may sometimes be appropriate to require the defendant to prove how damages should be apportioned, or be liable to the plaintiff for the entire harm. ${ }^{22}$ Holding the defendant liable for the entire harm without any consideration of the preexisting condition, however, is with one exception ${ }^{23}$ unsound. ${ }^{24}$ Even when a preexisting

20. E.g., Wilson v. Swinford, 324 So. 2d 582, 585 (La. Ct. App. 1975); Chrysler Corp. v. Todorovich, 580 P.2d 1123, 1130-31 (Wyo. 1978); see note 25 infra (criticizing Todorovich).

21. See RESTATEMENT (SECOND) OF TORTS § 433A, Comment i (1965). Under the traditional view, a tortfeasor may be jointly and severally liable to the plaintiff for the entire harm that he caused even if the acts of others may also have been causes of the same harm. See American Motorcycle Ass'n v. Superior Court, 20 Cal. 3d 578, 587, 578 P.2d 899, 904, 146 Cal. Rptr. 182, 187 (1978); W. PROSSER, supra note $3, \S 47$, at 297 . The tortfeasor may, however, have a right to seek contribution or indemnity from others who were tortiously liable to the plaintiff for the same harm. See generally RESTATEMENT (SECOND) OF TORTS $§ \S 886 \mathrm{~A}, 886 \mathrm{~B}$ (1979).

22. See pp. 1390-94 infra.

23. See p. 1362 infra (discussing the subsuming injury problem).

24. The Restatement position, although ambiguous, is probably consistent with this conclusion. Apart from the effects of shifting the burden of proof, see RESTATEMENT (SECOND) OF TORTS $\S$ $433 \mathrm{~B}(2)$ (1965), the Restatement would impose liability on a defendant for the entire harm when each force (including the defendant's) was a cause of the harm and the harm could not be apportioned reasonably. See id. $\S 433$ A \& Comment i. To the extent that another force was a preexisting condition, the defendant's conduct may not have been a cause of the harm, but only a part of it, and reasonable apportionment would not be impossible. Indeed, the Comments acknowledge that apportionment reflecting preexisting conditions may be appropriate, even when the end result appears indivisible. See id. \$ 433A, Comment c.

Other Restatement sections, while confusing, seem to represent a partial melding of sections $433 \mathrm{~A}$ and $433 \mathrm{~B}(2)$ with respect to precxisting conditions. See REST TTEMENT (SECOND) OF TORTS $\$ 879 \&$ Comment b (1979) (each tortfeasor liable for entire harm when each of two or more tortfeasors was "a legal cause of harm that cannot be apportioned," but rule not applicable when each causes a distinct harm or one person aggravates harm caused by another, except presumably for effect of possibly shifting burden of proof). For further elaboration of the Restatement position with respect to contributing tortfeasors, see id. $\$ \S 875,881$. 
condition and the defendant's tort may both have been but-for ${ }^{25}$ or substantial-factor ${ }^{26}$ causes of a specific end result, the loss caused by the defendant may not be the entire loss because the preexisting condition reduced the value of the interest the defendant destroyed.

The defendant should be subject to liability only to the extent that he tortiously contributed to the harm by allowing a preexisting condition to progress or by aggravating or accelerating its harmful effects, or to the extent that he otherwise caused harm in excess of that attributable soley to preexisting conditions. ${ }^{27}$ The effect of preexisting conditions should depend on the extent to which such conditions affect the present and future value of the interest lost. The practical effect of preexisting conditions on damages, however, may be significantly affected by the placement of the burden of proof. ${ }^{28}$

The rule that a victim's preexisting condition should ordinarily be

25. See, e.g., Dillon v. Twin State Gas \& Elec. Co., 85 N.H. 449, 163 A. 111 (1932) (discussed at pp. 1357-58 supra). A fall caused the victim to grasp the electric wire that killed him. The fall was thus a cause of his electrocution, as were the defendant's wires. The court held that the fall was a preexisting condition that had to be taken into account in assessing damages.

This problem is well illustrated in the "crashworthiness" cases of the products liability field. In these cases, the occurrence of the accident or "crash" had already placed the victim in jeopardy when the other factor-the allegedly defective condition that enhanced the injury or failed adequately to safeguard the victim from the effects of the crash-came into play. Under these circumstances the crash, and its potential consequences even without the defective condition, should be deemed a preexisting condition that should be taken into account in assessing the defendant's liability. See, e.g., Huddell v. Levin, 537 F.2d 726, 737-39 (3d Cir. 1976). Some courts impose joint and several liability on the defendant manufacturer when they perceive the end result to be indivisible. See Chrysler Corp. v. Todorovich, 580 P.2d 1123, 1130-31 (Wyo. 1978). This approach misses the point. Although the end result may be indivisible, the harm or loss attributable to the defendant's conduct may have been less than the total loss suffered, and therefore apportionable. An argument can be made in such cases that the defendant should have the burden of proving the extent to which the preexisting crash reduced the value of the interest destroyed. See generally pp. 1390-94 (Part II-D) infra (discussing burden of proof). Subjecting the defendant to liability for the entire harm suffered, however, without allowing him an opportunity to prove the effects of the preexisting condition, is tantamount to disregarding the preexisting condition. Moreover, the adoption of the method of valuing chance proposed in this article would make apportionment more feasible. See pp. 1376-81 infra. See generally note 135 infra (discussing possible rights to contribution or indemnity).

26. One of two substantial-factor causes (in the section 432(2) sense) of the same end result could still be deemed a preexisting condition. See generally RESTATEMENT (SECOND) OF TORTS $§ 432(2)$ (1965) (discussing substantial-factor exception to but-for rule). Consider a patient who has been given a dose of medication that a few minutes later causes shock, while at the same time hemorrhage from negligently performed surgery also induces shock. Assume that the patient dies of the combined shock and that the shock produced by either event alone would have been fatal. Each event could be deemed a substantial factor in producing the patient's death. Yet because the drug had been administered (had attached) prior to the surgical error, a strong argument can be made that the presence of the drug should be deemed a preexisting condition and taken into account in deciding what interest (including the chance of a more favorable outcome), if any, was destroyed by the defendant, and in determining the interest's value. For an apparently contrary view, see Basko v. Sterling Drug, Inc., 416 F.2d 417, 428-30 (2d Cir. 1969).

27. See, e.g., Stephens v. Koch, 192 Colo. 531, 533-34, 561 P.2d 333, 334 (1977); DeFelice v. Barberino Rental Corp., 157 Conn. 231, 234-35, 253 A.2d 37, 39 (1968); Valliere v. Filfalt, 110 N.H. 331, 332-33, 266 A.2d 843, 844-45 (1970); Potts v. Howser, 274 N.C. 49, 54, 161 S.E.2d 737, $741-42$ (1968).

28. See pp. 1390-94 infra. 
taken into account in assessing damages is in no way inconsistent with the time-honored doctrine that the defendant takes his victim as he finds him. ${ }^{29}$ Under this rule, sometimes referred to as the "thin skull" doctrine, the fact that the harm suffered by the victim exceeds the harm that one would reasonably have expected a normal person to suffer does not defeat liability or prevent the defendant's conduct from being a cause of the injury. The "take him as you find him" rule does not, however, make the victim's preaccident condition irrelevant. ${ }^{30}$ The preexisting condition of the victim should be considered in assessing the value of the interest destroyed or affected. That a terminally ill victim would have died on Tuesday, the next day, does not prevent the defendant's conduct from being a cause of his death on Monday, but would obviously be quite relevant to the question of damages. In essence, the "take him as you find him" rule simply means that the extent of the victim's actual injury from the accident need not have been reasonably foreseeable.

Although preexisting conditions generally should be taken into account in valuing the interest destroyed, a compelling argument can be made that the rule should be qualified when that condition is caused by tortious conduct and is followed by an injury not causally related to the prior injury, and the second injury subsumes and to some extent preempts the first. The first tortfeasor, $A$, might inflict an injury that results in complete

29. See note 30 infra (citing cases). See generally RESTATEMENT (SECOND) OF TORTS $§ 461$ (1965).

30. This distinction is articulated in numerous cases. See, e.g., Irving v. Bullock, 549 P.2d 1184, 1187 (Alaska 1976); Schore v. Mueller, 290 Minn. 186, 189, 186 N.W.2d 699, 701 (1971). Thus, in the Schore case, the court noted:

[A] person who has a preexisting disability is entitled to recover damages for an aggravation of that condition even though the particular consequences would not have followed absent his prior disability, recovery being limited, however, to the additional injury over and above the consequences which normally would have followed from the preexisting condition absent defendant's negligence.

Id. at 189,186 N.W.2d at 701 . In the leading case of McCahill v. New York Transp. Co., 201 N.Y. 22l, 223-24, 94 N.E. 616, 617 (1911), the fact that the auto accident victim, who was an alcoholic, suffered more severe consequences than a healthy person would have experienced did not defeat liability or mean that the defendant did not "cause" the injury. The victim's preexisting condition, however, was expressly held by the court to be a factor to be taken into account in assessing damages. Id. at 224,94 N.E. at 617.

Occasionally a court will fail to distinguish the two ideas. In Foster v. Baptist Mem. Hosp., 506 S.W.2d 775 (Tenn. Ct. App. 1974), the court began quite correctly with the general rule that the "tort feasor must accept the injured person as he finds him." Id. at 778. The court also correctly implied that the defendant would not be liable for medical expenses, loss of earnings, or pain and suffering experienced prior to the injury the defendant caused. Id. at 779. Unfortunately, the court went on to hold: "If the wrongful act results in the aggravation of, or an increase in, a permanent partial disability existing in the injured party, then it matters not to what extent the wrongful act aggravates or increases that disability; any increase thereof renders the tort feasor liable for all." Id. at 778 (emphasis added). Fortunately, the unsound portion of Foster appears not to have been followed. See Fuller v. Speight, 571 S.W.2d 840, 841 (Tenn. Ct. App. 1978) ("The fact that a party is in a weakened condition at the time of the injury is not a causal defense available to the defendant .... Such condition may be material to the issue of [damages] . . . .") (emphasis added); Haws v. Bullock, 592 S.W.2d 588, 590-91 (Tenn. Ct. App. 1979) (explaining Foster result on other grounds). 
paralysis of the plaintiff's right arm. One year later, but before a final decision on damages in the plaintiff's claim against $A$, a second tortfeasor, the defendant $B$, might inflict another injury to the arm, requiring its amputation. $A$ would assert, under what is perhaps the traditional view, that when a subsuming injury for which he bore no legal responsibility occurs prior to such a decision, he should be liable only for the actual accrued losses that materialized prior to the subsuming second injury. ${ }^{31} B$, on the other hand, would assert that he should be liable only for the value of the interest that he destroyed - the value of a paralyzed right arm plus any collateral damages attributable to the second injury or the amputation. Such a result is difficult to justify. That there were two tortfeasors would actually reduce the damages substantially below what they would have been for either injury alone. ${ }^{32}$

This anomaly can be rectified in several ways. One solution would be to calculate the amount of $A^{\prime}$ 's liability at the time of the initial injury without regard to subsequent events. A more reasonable solution entails reevaluating the nature of the loss caused by $B$. Not only has the defendant $B$ 's tortious conduct necessitated the amputation of the plaintiff's arm, it may also have foreclosed much of the plaintiff's potential recovery from $A$, the prior tortfeasor. Extrapolating from the "take him as you find him" concept, it can be argued that one of the risks with which the defendant takes his plaintiff is the risk that the injury inflicted by the defendant might subsume a prior unredressed injury by another tortfeasor, and thereby foreclose the plaintiff from receiving full compensation from the first tortfeasor. Thus $B$ should be held liable not only for the additional harm he caused, but also for the extent to which recourse against $A$ for actual losses subsequent to the second injury was prevented by the second tort, and such losses were not otherwise recoverable from $B$. This approach can be reconciled with the general rule that the value of a lost

31. See, e.g., Tucker v. Calmar S.S. Corp., 356 F. Supp. 709, 710-12 (D. Md. 1973); Jurney v. Lubeznik, 72 Ill. App. 2d 117, 132, 218 N.E.2d 799, 806 (1966); Victorson v. Milwaukec \& Suburban Transp. Corp., 70 Wis. 2d 336, 361, 234 N.W.2d 332, 344 (1975); RESTATEMENT (SECOND) OF TORTS § 910, Comment b (1979); id. § 924, Comment e; id. § 926(a) \& Comment a. But see Buchalski v. Universal Marine Corp., 393 F. Supp. 246, 249-52 (W.D. Wash. 1975). Although the foregoing authorities that support the rule addressed the problem of subsuming injuries in general, it is assumed for the purposes of the present discussion that their analysis would also apply in the context of subsuming tortious injuries as well. Buchalski, which rejected the rule generally, contains dicta similarly rejecting it in that context. Id. at 250-51. For a possible limitation to the rule, see notes 32 and 135 infra.

The first tortfeasor would rely on an extension of the general rule that damages are determined in light of all the evidence presented at trial concerning the harm that has resulted or probably will result from the tortious conduct. See RESTATEMENT (SECOND) OF TORTS § 9l0, Comment b (1979).

32. The foregoing analysis assumes that the harm was reasonably capable of apportionment between the two torts. Were this not so, a different result might follow if the burden of proving apportionment were shifted to either or both tortfeasors. See note 135 infra. See generally pp. 1390-94 infra. 
interest should reflect any preexisting conditions. Although on the one hand the plaintiff's preexisting condition would reduce the value of the lost interest, that value would be augmented by the value of the plaintiff's potential claim against $A$ for actual subsequent losses, which he lost due to defendant $B$ 's tort.

A more complex case may arise when the conduct of $A$, the first tortfeasor, while threatening the victim with harm, has not yet actually inflicted harm at the time of the second injury. It is at least conceivable that the effect of $A$ 's conduct might be cognizable as a preexisting condition and yet not have developed enough at the time of the second injury to have given rise to a cause of action against $A$. Again, $B$, the second tortfeasor, should be held liable not only for the harm he added, but also for the damages for actual losses that otherwise would have been recoverable from $A$ but were preempted by $B$ 's conduct. ${ }^{33}$

\section{Causation and Valuation in the Context of Preexisting Condi- tions and Future Consequences}

Causation has for the most part been treated as an all-or-nothing proposition. Either a loss was caused by the defendant or it was not. Inexplicably, the all-or-nothing approach of the causation inquiry has been allowed to slip its analytical moorings, influencing the identification and valuation of losses in cases involving preexisting conditions and claims for future consequences. A plaintiff ordinarily should be required to prove by the applicable standard of proof that the defendant caused the loss in question. What caused a loss, however, should be a separate question from what the nature and extent of the loss are. This distinction seems to have eluded the courts, with the result that lost chances in many respects are compensated either as certainties or not at all.

To illustrate, consider the case in which a doctor negligently fails to diagnose a patient's cancerous condition until it has become inoperable. Assume further that even with a timely diagnosis the patient would have had only a $30 \%$ chance of recovering from the disease and surviving over the long term. There are two ways of handling such a case. Under the traditional approach, this loss of a not-better-than-even chance of recovering from the cancer would not be compensable because it did not appear more likely that not that the patient would have survived with proper

33. See W. PROSSER, supra note $3, \S 52$, at 322 . One commentator would reach a similar result under a somewhat different analysis. See Peaslee, supra note 19, at 1137-38. Justice Peaslee reasoned that if "[t]he situation of threatened wrong still leaves the plaintiff possessed of all the values he had before.... [then t] he prospective harm has not impaired that value, because the prospect of an accrued right to recover the damage from the offender keeps strict pace with that of impending injury." Id. at 1137 (emphasis added). 
care. Recoverable damages, if any, would depend on the extent to which it appeared that cancer killed the patient sooner than it would have with timely diagnosis and treatment, and on the extent to which the delay in diagnosis aggravated the patient's condition, such as by causing additional pain. A more rational approach, however, would allow recovery for the loss of the chance of cure even though the chance was not better than even. The probability of long-term survival would be reflected in the amount of damages awarded for the loss of the chance. While the plaintiff here could not prove by a preponderance of the evidence that he was denied a cure by the defendant's negligence, he could show by a preponderance that he was deprived of a $30 \%$ chance of a cure.

\section{A. Traditional Rules and Approaches}

In analyzing the treatment of chance in tort claims involving preexisting conditions and future consequences, it is useful to distinguish two types of losses. The first, which might be called a definitive loss, involves the loss of a chance either of completely avoiding a specific harm or of achieving a fairly definitive favorable result. These types of claims include both materialized losses and anticipated future consequences (including loss of future benefits). A plaintiff might assert, for example, that had the decedent received timely treatment, he would not have died from the disease.

The second type of loss consists of losses that might be called partial or less definitive losses. These include losses other than the chance of avoiding completely some untoward result or of achieving completely some specific benefit. They include materialized and future partial losses due to aggravation or acceleration of the untoward effects of a preexisting condition, or to acceleration of some adverse preordained result, as well as claims for future consequences that are less than definitive. Thus, even if a plaintiff could not recover for the lost chance of being cured of cancer, he might still be entitled to recover for aggravation of its untoward effects or acceleration of the moment of death. Regardless of whether preexisting conditions are involved, a significant portion of partial losses will be in the form of future consequences. Moreover, the process of proving and estimating damages for both definitive and partial losses may be subject to much the same analysis as is applied to partial losses, and is addressed in that section of the article. ${ }^{34}$ Although the all-or-nothing principle operates in the context of partial or less definitive losses, including the loss of a chance of avoiding such losses, it operates less completely. ${ }^{35}$ In addition, claims for more than one type of loss will often be asserted as a result of a

34. See pp. 1373-76 infra.

35. See p. 1374 infra. 
single injury, subject only to the obvious limitation that there should be no double recovery. Glaims for either type of loss may arise from passive injuries due to omissions (such as failure to diagnose a disease) or from actively inflicted injuries (such as a surgical incision).

The two basic loss types will be discussed in two of the three sections that follow. ${ }^{36}$ General principles relating to losses attributable to future consequences from a tortious injury will be discussed briefly in a separate section. ${ }^{37}$ Because, however, such losses may consist of either definitive or partial losses, discussion of future consequences will largely be integrated into the sections addressing the two basic loss types.

\section{Loss of a Chance of Complete Loss Avoidance}

The first type of loss involves the destruction of a chance of completely avoiding an adverse result or of achieving a definitive favorable result. Most courts have misperceived the nature of the interest destroyed by failing to identify the destroyed chance itself as the compensable loss. Instead, they have treated the chance of avoiding the loss as if it were either a certainty or an impossibility, depending on whether, (under the traditional standard of proof) the tortiously reduced likelihood of loss avoidance was better than even. Thus, the plaintiff will recover for a lost opportunity only if it appears more likely than not that but for the tort some definitive adverse result would have been avoided. His recovery, however, will not be discounted by the chance that the loss might have occurred even absent the tort. Conversely, the plaintiff recovers nothing for the lost chance if the probability of that chance does not rise to the level required by the applicable standard of proof. $^{38}$

The majority of personal injury torts cases that have confronted the question have adopted an all-or-nothing approach to the loss of a chance. ${ }^{39}$ Only a few personal injury cases have recognized, even implicitly, the loss

36. See pp. 1365-70, 1373-76 infra.

37. See pp. 1370-73 infra.

38. The Ohio case of Kuhn v. Banker, 133 Ohio St. 304, 13 N.E.2d 242 (1938), provides an example of the all-or-nothing rule in the passive injury situation. The plaintiff alleged that the defendant-physician negligently failed to discover the disunion of a fracture of her thigh bone that had initially united after being set. When the disunion was discovered it was too late to attempt another union. Surgery was necessary, and afterwards the plaintiff remained significantly disabled. Expert testimony indicated that even if the defendant had made a timely discovery of the disunion, the likelihood of successfully achieving a second union was not better than $35 \%$. The Ohio Supreme Court affirmed the trial court's decision to direct a verdict for the defendant. The standard of proof in Ohio required that the plaintiff establish that it was probable that a positive outcome would have been achieved but for the defendant's negligence. The court expressly held that the plaintiff was not entitled to damages for the "loss of a chance of recovery" when the chance of successful recovery was not better than even. Id. at $310-15,13$ N.E.2d at $244-47$.

39. See notes 44-46, 53-55 infra (citing sources). 
of a chance as a compensable interest valued in its own right. ${ }^{40}$

The adoption of the all-or-nothing approach to the loss of a chance has the obvious effect of enhancing the importance of the standard of proof, which determines the degree of certainty with which the party with the burden of proof ${ }^{41}$ must satisfy that burden in order to prevail. Perhaps for this reason, when results under the all-or-nothing rule have appeared too harsh to courts, attention has generally focused on the standard of proof as the appropriate doctrine for reformulation. Three different standards of proof have been applied with respect to the compensability of a lost chance under the all-or-nothing rule. In order of their onerousness to the party with the burden of proof, they are the "actual certainty" standard, the prevailing "more likely than not" standard, and the "reasonable possibility" standard. The problem, however, is not the standard of proof, but the object to which that standard is applied: the interest for which redress is sought. Viewing the matter as a standard-of-proof issue has prevented analysis of the real problem, the all-or-nothing approach to the loss of a chance. ${ }^{42}$

40. See p. 1380 \& notes $95-96$ infra.

41. For the sake of simplicity, it is assumed here that the burden of proof would remain on the plaintiff. This is not always so, however, nor should it be. See generally pp. 1390-94 infra.

42. Expert testimony is often required in causation-valuation questions. When it is required, courts usually require that it be expressed in terms that are equivalent to the applicable standard of proof in order to be sufficient to support a verdict. See, e.g., Davis v. P. Gambardelli \& Son Cheese Corp., 147 Conn. 365, 373, 161 A.2d 583, 587 (1960); Laskowski v. Wallis, 58 Del. 98, 101-02, 205 A.2d 825, 826-27 (1964); Jolicoeur v. Conrad, 106 N.H. 496, 498-99, 213 A.2d 912, 914 (1965); Martin v. Stratton, 515 P.2d 1366, 1371 (Okla. 1973). Thus, if the traditional "more likely than not" standard of proof is applicable, the expert is frequently required to testify in those or equivalent terms. Some courts have even stated that unless the testimony is expressed in such terms, it is inadmissible. See, e.g., Davidson v. Miller, 276 Md. 54, 58-62, 344 A.2d 422, 425-28 (1975); Scott County Co-op v. Brown, 187 So. 2d 321, 325-26 (Miss. 1966); O’Donoghue v. Riggs, 73 Wash. 2d 814, 82225, 440 P.2d 823, 829-30 (1968).

One cannot, however, infer that a court's decision to uphold the admissibility of expert testimony expressed in terms less probative than the prevailing more-likely-than-not standard, or to uphold the sufficiency of the evidence in such a case, signifies adoption of a more lenient standard of proof. While it is possible that the court intended to adopt a more lenient standard, this is rarely the case. There are other, more likely, explanations of such decisions. First, while adhering to the more-likely-thannot standard of proof, the court may have found that there was sufficient evidence to support a verdict, even though testimony from a specific expert was expressed in less probative terms, because testimony expressed with a higher level of certainty from this expert was not necessary to uphold the verdict. There may, for example, have been other probative evidence that was sufficient when taken in conjunction with this expert's testimony; or there may have been other expert testimony that was sufficiently probative; or the facts may have been cognizable to laymen, and expert testimony therefore unneeded. Second, the court may have preferred to admit such expert testimony and to reserve decision on whether, considering all of that party's evidence, there was sufficient showing to submit the case to the trier of fact. Sec, e.g., Dickinson v. Mailliard, 175 N.W.2d 588, 591 (Iowa 1970); Gibson v. Avery, 463 S.W.2d 277, 280 (Tex. Civ. App. 1970). Courts are generally more lenient on questions of admissibility than on questions of sufficiency. On the distinction between relevancy and sufficiency of evidence, see C. MCCORMICK, MCCORMICK'S HANDBOOK OF THE LAW OF EVIDENCE § 185, at 436 (2d ed. E. Cleary 1972). Third, the court may have found that, despite some language ostensibly couched in less probative terms, the expert's testimony taken as a whole was sufficiently probative of the traditional standard of proof. Occasionally, a court may approve expert testimony expressed in less 
The all-or-nothing concept of chance has usually been applied to definitive losses regardless of which standard of proof was adopted. Thus, variations in the standard of proof may determine upon whom the loss will fall, but the all-or-nothing nature of that loss is determined by the court's attitude towards the place of chance in the concept of injury.

Of the three different standards of proof, the actual certainty formulation $^{43}$ is the least prevalent. ${ }^{44}$ This is not surprising, since the very idea of certainty of unknown and future events is implausible.

The second standard of proof, termed the "preponderance of the evidence" rule or the "more likely than not" standard, is the most widely followed approach not only for causation questions in general, but also under the all-or-nothing approach to loss of a chance. ${ }^{45}$ This rule denies compensation for the loss of a not-better-than-even chance of avoiding some adverse result.

An Ohio malpractice case illustrates the operation of the more-likelythan-not standard of proof in conjunction with the all-or-nothing ap-

probative terms than the applicable standard of proof under the misguided concern that more definitive testimony would invade the province of the jury. Although the old rule was that the expert should not be permitted to express an opinion on an ultimate factual issue, the majority of courts now permit an expert opinion on an ultimate fact, at least when it does not express a belief as to how the case should be decided. Id. $\S 12$, at $26-27$.

The preceding observations relate to causation-damages questions in general and are not limited to the present context.

43. The actual certainty standard of proof should be distinguished from the "reasonable certainty" standard by which it is commonly said that future consequences and damages in general must be established. Although the meaning of the latter phrase in tort law is often unclear, actual certainty is usually not required. See pp. 1371-72, 1374-75 infra.

44. Although courts seldom adopt an actual certainty standard of proof, a few have approached that result by requiring that an expert's conclusion be expressed in terms approaching that level of certainty. A court will occasionally go even further. One court not only held that testimony that the decedent had lost a 75\% chance of survival was insufficient, but also seemed to approve an actual certainty standard of proof. See Hamil v. Bashline, 243 Pa. Super. 227, 235-36, 364 A.2d 1366, 1370 (1976), vacated, $481 \mathrm{~Pa}$. 256, 392 A.2d 1280 (1978). The supreme court, in reversing, reaffirmed the traditional more-likely-than-not standard of proof and relaxed the expert witness requirements in the instant context, but failed to harmonize adequately the standard of proof and the required form of expert testimony. Despite semantic variations, most courts do not require that an expert find causation with a greater degree of certainty than the applicable standard of proof (which usually requires that causation was probable).

45. See, e.g., W. PROSSER, supra note 3, § 41, at 241-42; RESTATEMENT (SECOND) OF TORTS $\S$ 433B, Comment b (1965) ("It is enough that [the plaintiff] introduces evidence from which reasonable men may conclude that it is more probable that the event was caused by the defendant than that it was not.")

The operation of the more-likely-than-not standard of proof in conjunction with the all-or-nothing approach to the loss of a chance is found in numerous medical malpractice cases involving passive injuries. See, e.g., Rewis v. United States, 503 F.2d 1202, 1204-05 (5th Cir. 1974) (must appear more likely than not that, absent alleged negligence, child's life would have been saved); Bryant v. Rankin, 468 F.2d 510, 515 (8th Cir. 1972) (evidence must prove that but for failure of doctors to diagnose infection, permanent disability would probably be avoided); Davis v. Kemp, 252 Ark. 925, 927, 481 S.W.2d 712, 713 (1972) (must appear probable that but for alleged negligence, complications would not have ensued); Schenck v. Roger Williams Gen. Hosp., 382 A.2d 514, 518-19 (R.I. 1977) (must appear that there was reasonable probability that but for alleged negligent diagnosis, patient would not have suffered injuries claimed). 
proach to the loss of a chance in the passive injury context. In Cooper v. Sisters of Charity, ${ }^{46}$ the plaintiff alleged negligence in diagnosis and treatment of the decedent, who had suffered a skull fracture in an accident. At trial, one physician called as an expert witness by the plaintiff indicated that " there is no possible way . . . to ascertain with any degree of certainty whether with medical intervention, the individual would have survived or died." "47 Another of the plaintiff's expert witnesses testified that there was about a $50 \%$ chance that the victim would have survived had surgery been performed. ${ }^{48}$

The Ohio Supreme Court affirmed a directed verdict for the defendant, holding that the plaintiff had failed as a matter of law to establish the requisite causal connection between the allegedly negligent act and the decedent's death. The court held that the "plaintiff in a malpractice case must prove that defendant's negligence, in probability, proximately caused the death." The court defined "probability" as "that which is more likely than not,"50 and added that "[p]robable is more than $50 \%$ of actual.",51

The third standard of proof on the question of the compensability of a chance is the "substantial possibility" rule. This standard, most commonly found in the passive injury context, entitles a plaintiff to recover for a loss even when there was proof of only a substantial possibility that the result complained of would have been avoided but for the tortious conduct. Under this standard, not only could plaintiffs recover for the loss of a notbetter-than-even chance of some favorable result, but the recovery probably would not be discounted to reflect the magnitude of the chance. ${ }^{52} \mathrm{~A}$ number of recent decisions, although a minority even in the passive injury context, ostensibly adopt the substantial possibility standard. Careful examination of many of these cases suggests, however, that their support for this rule is often limited, problematic, or ambiguous. ${ }^{53}$

46. 27 Ohio St. 2d 242, 272 N.E.2d 97 (1971).

47. Id. at 247,272 N.E.2d at 101.

48. Id.

49. Id. at 252,272 N.E.2d at 103.

50. Id. at 253,272 N.E.2d at 104 .

51. Id.

52. Thus, the substantial possibility standard of proof probably does not dispense with the all-ornothing approach; it merely improves the plaintiff's odds of receiving all rather than nothing. It is possible, of course, that courts in some of the substantial possibility cases may have perceived the problem in terms of compensating loss of a chance valued as such. It is impossible to tell from the opinions, but one suspects that these courts contemplated a continuation of the all-or-nothing approach to chance.

53. Ironically, the case most often cited as a leading proponent of the substantial possibility standard of proof in the passive-injury, preexisting-condition context endorsed that standard in dicta. In Hicks v. United States, 368 F.2d 626 (4th Cir. 1966), the plaintiff's decedent died from an obstruction of the intestine. The plaintiff alleged that a Navy doctor was negligent in misdiagnosing the patient's condition. On appeal, the court of appeals reversed the district court's dismissal of the complaint, 


\section{Causation and Valuation}

\section{The foregoing analysis has focused primarily on the passive injury situ-}

rejecting the district court's conclusion that the plaintiff had failed to prove that the doctor's negligence was the cause of the patient's death. In so holding, the court of appeals proferred the following language, which has become a favorite mooring for courts favoring the substantial possibility standard of proof:

When a defendant's negligent action or inaction has effectively terminated a person's chance of survival, it does not lie in the defendant's mouth to raise conjectures as to the measure of the chances that he has put beyond the possibility of realization. If there was any substantial possibility of survival and the defendant has destroyed it, he is answerable. Rarely is it possible to demonstrate to an absolute certainty what would have happened in circumstances that the wrongdoer did not allow to come to pass. The law does not in the existing circumstances require the plaintiff to show to a certainty that the patient would have lived had she been hospitalized and operated on promptly.

Id. at 632 (emphasis added to "substantial possibility"). This language, taken at face value, seems to permit redress when the chance of a patient's recovery from a preexisting disease or the chance of some other favorable result was, even with proper care, not better than even. The Hicks language, however, was dicta. The uncontradicted testimony of the plaintiff's experts was that "if operated on promptly, [the patient] would have survived." Id. This testimony more than satisfied the more-likelythan-not standard of proof. Moreover, by saying that " $[t]$ he law does not in the existing circumstances require the plaintiff to show to a certainty that the patient would have lived," id., the court suggests that it was rejecting the actual certainty standard of proof but not necessarily the more-likely-than-not standard. Some subsequent decisions have given Hicks this narrow reading. This was apparently the interpretation rendered by the same court two years later. See Clark v. United States, 402 F.2d 950, 953-54 (4th Cir. 1968) (by implication); of. Whitfield v. Whittaker Memorial Hosp., 210 Va. 176, 183-84, 169 S.E.2d 563, $568-69$ (1969) (mirroring Hicks ambiguity).

A number of other malpractice cases expressly or tacitly purport to adopt the substantial possibility standard of proof. Upon careful examination, however, many of these cases have features that may limit their precedential force or scope. In some cases the courts seem to have been swayed by the fact that the defendant was alleged to have negligently abandoned the plaintiff. See Ascher v. Gutierrez, 533 F.2d 1235, 1237-38 (D.C. Cir. 1976) (sufficient that jury could have concluded that but for alleged abandonment of plaintiff, he might not have suffered brain damage); of. Maltempo v. Cuthbert, 504 F.2d 325, 328 (5th Cir. 1974) (sufficient that jury could have found that had defendant not failed to see patient, patient's death "might well have been averted"); Thomas v. Corso, $265 \mathrm{Md}$. $84,102,288$ A.2d 379, 390 (1972) (sufficient that jury could have found that alleged failure of doctor to attend to decedent destroyed "substantial possibility" that he would have survived). See generally J. KING, supra note 4, at 25 (discussing abandonment).

In some other cases, the court's arguable approval of the substantial possibility standard was ambiguous because of a failure expressly to adopt that standard. In Hernandez v. Clinica Pasteur, Inc., 293 So. 2d 747 (Fla. Dist. Ct. App. 1974), the court held that expert testimony that decedent "would have had a better chance to survive if he had received prompt medical attention was sufficient to form a basis for the submission of the issue to the jury." Id. at 750. It is not clear, however, whether the court intended to adopt a substantial possibility standard of proof, or for some reason found the evidence sufficient even though the expert testimony was expressed in less probative terms than the traditional standard of proof. For a similar ambiguity, see Truan v. Smith, 578 S.W.2d 73 (Tenn. 1979).

A few cases appear to afford stronger support for the rule. In Kallenberg v. Beth Israel Hosp., 45 A.D.2d 177, 357 N.Y.S.2d 508 (1974) (per curiam), affd mem., 37 N.Y. 719, 337 N.E.2d 128, 374 N.Y.S.2d 615 (1975), for example, the plaintiff's own expert testified that even if the decedent had received timely treatment and thereafter had undergone surgery, she would only have had a $20 \%$ to $40 \%$ chance of survival. Id. at 179-80, 357 N.Y.S.2d at 510-11. Other physicians testified only that there was a "possibility" of the decedent's being saved. Id. at 181, 357 N.Y.S.2d at 512 (Steuer, J., dissenting). The appellate division held that the jury could find that had the decedent been given proper medication, her blood pressure "could have been" controlled and she "might have improved sufficiently" to undergo surgery and make recovery. Id. at 180, 357 N.Y.S.2d at 511 . The appellate division affirmed the judgment for the plaintiff, essentially approving the finding of causation under these circumstances. For an explanation of Kallenberg, see Kimball v. Scors, 59 A.D.2d 984, 399 N.Y.S.2d 350 (1977).

Some courts also have in various ways relaxed the traditional standard of proof in some special statutory or factual contexts. See, e.g., Gardner v. National Bulk Carriers, Inc., 310 F.2d 284, 287 (4th Cir. 1962), cert. denied, 372 U.S. 913 (1963) (duty to attempt rescue of overboard seaman). 
ation. The same analysis can be applied to the active injury context. A plaintiff could claim that, as a result of the intervention of the defendant's tortious conduct, he lost the chance to recover from the preexisting condition or otherwise avoid some untoward consequence of it. The all-or-nothing view of chance would, under one formulation of the prevailing standard of proof, deny relief for the loss of a not-better-than-even chance of the favorable result claimed. ${ }^{54}$ For example, a victim of cancer could be killed on the operating table because of negligently administered anesthesia. The plaintiff would recover for the extent to which the decedent's death was accelerated, but would receive no damages for the value of the decedent's chance of being cured of the disease unless that chance rose to the requisite level..$^{55}$

Attempts to deal with the problem posed by the destruction of a chance by tinkering with the standard of proof can only further confuse matters of loss assignment. If the law on this question is to be rationalized, a vehicle other than the standard of proof will have to be used. The appropriate vehicle is a reevaluation of the traditional ways of thinking about the interest for which relief is sought and the role of chance in valuing that interest.

\section{Losses Based on Future Consequences}

Damages in personal injury tort actions are traditionally awarded in a single lump sum that is intended fully to compensate the plaintiff for all past and future consequences ${ }^{56}$ of the tort. This approach has required

54. Under one formulation, damages would be recoverable only to the extent that the victim probably would have avoided future harm in the absence of the tort, and thus there would be no recovery for loss of a not-better-than-even chance of avoiding future harm. See, e.g., Huddell v. Levin, 537 F. 2d 726, 737-40 (3d Cir. 1976); Howell v. Nichols, 22 N.C. App. 741, 743-44, 207 S.L.2d 768, 7707l, cert. denied, 286 N.C. 211, 209 S.E.2d 316 (1974). Some courts use a somewhat different formulation of the more-likely-than-not standard, stating that damages may not be awarded to the extent that the preexisting condition would probably have produced future harm independent of the tort. See, e.g., Steinhauser v. Hertz Corp., 421 F.2d 1169, 1173-74 (2d Cir. 1970); Kegel v. United States, 289 F. Supp 790, 795 (D. Mont. 1968); Dillon v. Twin State Gas \& Elec. Co., 85 N.H. 449, 456-57, 163 A. 111, 114-15 (1932). Taken literally, this latter formulation might allow recovery for a loss of an even chance of loss avoidance.

A few courts speak in terms of reducing damages because of preexisting conditions when it appears that the preexisting condition was "bound" to worsen. See, e.g., Henderson v. United States, 328 F.2d 502, 504 (5th Cir. 1964). This language may imply that a somewhat greater likelihood of future effects from the preexisting condition would have to be found before the preexisting condition would affect a defendant's liability, thus suggesting a divergence of opinion on the standard of proof in the active injury situation.

55. See, e.g., Huddell v. Levin, 537 F.2d 726, 737-40 (3d Cir. 1976); Dillon v. Twin State Gas \& Elec. Co., 85 N.H. 449, 163 A. 111 (1932) (discussed at p. 1357 supra). Although the court in Dillon recognized that the youth's fall prior to his fatal contact with the electrical wires was a preexisting condition, the court also noted that "[i]f it were found that he would have thus fallen with death probably resulting, the defendant would not be liable, unless for conscious suffering found to have been sustained from the shock." Id. at 457, $163 \mathrm{~A}$. at 115 (emphasis added).

56. Damages for future losses may be affected by rules that may require some types of damages, 
triers of fact to peer into the future in an effort to arrive at an appropriate damages award based upon the anticipated consequences of the tortious conduct. This problem has two dimensions. The first is whether a tortiously induced condition will continue or develop in the future. The second is how that condition, if it does continue or develop, will affect the victim's future interests, a determination that will depend on what those interests will be and otherwise would have been.

The issues presented by claims for future consequences and by the effects of preexisting conditions on such claims are similar analytically to those involving materialized losses and preexisting conditions. Under the traditional approach, it must be established under the applicable standard of proof that the future consequences that will be attributable to the defendant's tortious conduct rather than to other forces, such as preexisting conditions, are sufficiently likely to occur. Unless these conditions are met, the plaintiff will not recover for the particular loss.

Future consequences include both loss of a chance of completely avoiding some future loss and future losses of a less definitive nature. The impact of the all-or-nothing principle may vary depending on the type of future loss involved. Moreover, claims for future consequences and losses will figure centrally in the determination of damages generally. ${ }^{57}$

There have been several formulations of the standard of proof applicable to losses based on future consequences. The most common formulation requires that the prospect of future consequences and concomitant losses attributable to the tortious conduct be established, with expert testimony when needed, ${ }^{58}$ with "reasonable certainty." entirely clear or consistent as to the meaning of this phrase. Most courts agree that proof of a mere possibility of future consequences will not suffice, ${ }^{60}$ but that actual certainty is not necessary. ${ }^{61}$ The "reasonable certainty" standard thus lies somewhere between speculation and actual certainty. The confusion is compounded by the tendency of some courts to

such as loss of future earnings, to be reduced to present value, and by questions such as the place of inflation in assessing such damages. Sce D. DOBBS, HANDBOOK ON THE LAW OF REMEDIES $\S 8.7$ (1973); RESTATEMENT (SECOND) OF TORTS $§ 913 A$ (1979); Note, Future Inflation, Prospective Damages, and the Circuit Courts, 63 VA. L. REV. 105 (1977). These and other general damages matters are beyond the scope of this article.

57. That determination will in many respects be subject to the analysis developed in the next section. See pp. 1373-76 infra.

58. See Annat., 18 A.L.R.3d 10, 22-23 (1968); Annot., 18 A.L.R.3d 88, 101-02 (1968); Annot., 18 A.L.R.3d 170, 183-85 (1968).

59. See, e.g., Annot., 18 A.L.R.3d 10, 21 (1968) (future pain and suffering); Annot., 18 A.L.R.3d 88, 97 (1968) (impaired earning capacity); Annot., 18 A.L.R.3d 170, 182 (1968) (permanence of injury).

60. See Annot., 18 A.L.R.3d 10, 24 (1968); Annot., 18 A.L.R.3d 88, 97 (1968); 18 A.L.R.3d 170, 182 (1968); note 62 infra (citing cases).

61. See Townsend v. Stamper, 398 S.W.2d 45, 50 (Ky. 1965); Duchene v. Wolstan, 258 N.W.2d 601, 605-06 (Minn. 1977); note 59 supra (citing authorities). 
use other terminology. Many courts would probably equate "reasonable certainty" with the more-likely-than-not standard of proof, or would expressly adopt the latter standard. ${ }^{62}$ As will be seen in the next section, however, once it is established that a specific consequence or loss will occur and that the question before the trier of fact relates only to its extent or amount, the standard of proof has frequently been articulated somewhat differently. ${ }^{63}$

There is, then, no recovery for future consequences or losses under the traditional rule, unless it appears more likely than not that such a consequence or loss will occur that will be attributable to the tortious conduct. In other words, it would have to appear that the defendant destroyed a better-than-even chance of avoiding a future condition by reducing by $51 \%$ the likelihood of avoiding it. ${ }^{64}$ Absent this, the all-or-nothing rule operates to deny redress for the chance of such future consequences.

Some courts, however, have exhibited a more rational attitude. The most notable example is the Oregon case of Feist v. Sears, Roebuck \& $C 0^{65}$ Although the Feist court did not expressly recognize the compensability of the loss of a not-better-than-even chance of future consequences, it accomplished nearly the same result by allowing recovery for the tortiously created "susceptibility" to a future disease rather than for the actual future materialization of the disease. ${ }^{66}$ Feist and several other cases, ${ }^{67}$ although representing a minority view, suggest that the traditional reluctance to allow damages for loss of a chance may be less intractable in some future consequences contexts. Perhaps the notion of susceptibility is easier to conceive of rationally than are other types of chances. There is an obvious similarity between the notion of loss caused by a chance of future consequences and loss caused by a susceptibility of future consequences. Feist and similar cases thus represent an important step away from the all-or-nothing principle and in the direction of a straightforward recognition of the loss of a chance as a compensable interest valued in its own right.

The results produced by a misalliance of the more-likely-than-not stan-

62. See, e.g., Healy v. White, 173 Conn. 438, 443-45, 378 A.2d 540, 544 (1977); Davidson v. Miller, 276 Md. 54, 62, 344 A.2d 422, 427-28 (1975); Blakeman v. Gopp, 364 P.2d 986, 992 (Wyo. 1961).

63. See p. 1375 infra.

64. Thus, even if a preexisting condition contributed a $40 \%$ likelihood of a future loss, and the tort contributed an additional $45 \%$ likelihood, making it very likely that the loss would occur, the tortiously created chance would not be compensable under the traditional rule. The probability that a loss will occur that would be a materialization of the tortiously created risk would be only $45 \%$.

65. 267 Or. 402, 517 P.2d 675 (1973). For a further discussion of the Feist case and its extension in a later Oregon case, see note 96 infra.

66. 267 Or. at 410,517 P.2d at 679.

67. See J. STEIN, DAMAGES AND RECOVERY § 106 (1972). 
dard of proof and the all-or-nothing approach to loss of a chance are difficult to justify. The plaintiff who is able to demonstrate a probability of $50 \%$ or less that some future loss attributable to the tort will occur will be denied redress for that prospective loss. Yet it is manifest that the plaintiff's interests have been adversely affected.

Future consequences frequently will be deemed partial losses or part of the damages determination, and may be subject to a more limited application of the all-or-nothing concept. ${ }^{68}$

\section{Partial or Less Definitive Losses and Damages Estimation}

In some situations, the plaintiff will claim that some partial or less definitive loss did or will result from the tort. In connection with preexisting conditions, these partial or less definitive losses may include claims that the tort aggravated a preexisting condition, delayed its cure, failed to slow its progress, accelerated the onset of harm, or will have such effects in the future. Thus, even if the plaintiff is not entitled to recover for the loss of a chance of completely avoiding some specific harm, such as cancer-induced death, he might still be entitled to recover for the loss of a chance to slow the course of the disease or to mitigate its painful effects. The less definitive types of losses will invariably involve future consequences and loss of future benefits, regardless of whether a specific preexisting condition is implicated. Moreover, assessment of damages for both definitive and partial losses is subject to much the same type of analysis as that for partial losses; indeed, the ideas-proving partial losses and proving damages-may often overlap. Thus, even when a definitive loss of a chance of completely avoiding some adverse result has been proved, it still must be determined what the damages were-what losses would have been avoided and what benefits achieved had there in fact been complete avoidance. This damages inquiry in many respects involves essentially the same type of analysis as that which is applied to partial losses. The defendant generally is held liable only for the extent to which it appears that the harm exceeds or will exceed what otherwise would have occurred in the absence of the tort, ${ }^{69}$ or, under a substantial-factor formulation, for the harm that his tortious conduct was a substantial factor in producing. ${ }^{70}$

The all-or-nothing principle has been applied to the loss of a chance of avoiding a partial loss, but in a more limited manner. It still must be established (or disproved, if the burden of proof is shifted to the defendant) under the applicable standard of proof that a tortiously engendered

68. See pp. 1373-76 infra.

69. See pp. $1360,1361 \&$ note 30 supra.

70. See p. 1356 \& note 26 supra. 
harm did or will occur. Short of this proof, the mere possibility of such harm is insufficient for recovery. Under the traditional standard of proof, there is no recovery for the loss of a not-better-than even chance of avoiding some partial loss. ${ }^{71}$ Once some tortiously engendered partial loss, such as the loss of a better-than-even chance of avoiding some adverse result, is established, however, the issue becomes the extent of the loss. The all-ornothing concept does not operate in this estimation process because the loss of any chance is automatically integrated into the estimate of the partial or less definitive loss. That estimate should represent the last point (or highest figure) at which the chance that nontortious conduct would have averted the particular level of harm was still greater than the chance that it would not have done so. ${ }^{72}$

It is usually much easier to establish that a better-than-even chance of avoiding at least some partial or less definitive loss has been destroyed than it is to establish the loss of an opportunity for achieving some fairly definitive result, such as a full recovery from a disease. Therefore, the allor-nothing approach to the loss of a chance tends to work less hardship and introduces less distortion into the loss-assigning function when applied to aggravation-acceleration losses and other partial losses than when applied to more definitive losses.

A similar analysis applies to the assessment of damages. Once at least some damages of a specific type attributable to a specific tortiously induced condition have been proved, the question becomes one of estimation, an inquiry in which the all-or-nothing principle does not operate.

Courts commonly state that damages must be established with "reasonable certainty." ${ }^{\prime 3}$ In considering the proof of damages in general, especially with respect to the threshold question of whether there are some specific types of losses or damages attributable to the tort, many recent tort cases either equate "reasonable certainty" with the traditional more-

71. See, e.g., Grody v. Tulin, 170 Conn. 443, 450-51, 365 A.2d 1076, 1079-80 (1976) (must appear reasonably probable that but for alleged failure to perform timely surgery, patient's life would have been prolonged). For various formulations of the standard of proof on the compensability of a lost chance under the all-or-nothing approach, see pp. 1365-70 supra.

72. For example, a plaintiff might claim that because of a delay in making a diagnosis, his convalescence was needlessly prolonged with resulting harm. Under the traditional rules, damages would be the product of a two-part inquiry. First, it would have to appear more probable than not that there was at least some added convalescence attributable to the defendant's tortious conduct-in other words, that the plaintiff lost a better-than-even chance of avoiding some partial loss. Second, assuming that this threshold determination were made, the trier of fact would have to estimate the extent of the added convalescence. In this latter inquiry, the plaintiff in effect is given credit for the chance that an even greater proportion of his convalescence was attributable to the defendant's conduct; that chance, however, is discounted by (and discounts) the existence of the same chance that the opposite is true. Thus, the chance that a better result could have been achieved but for the defendant's tortious conduct is taken fully into account in arriving at an estimate of the loss.

73. See D. DoBBS, supra note $56, \S 3.3$, at 150 ; note 59 supra (citing authorities). 
likely-than-not standard of proof, use a reasonably probable standard, ${ }^{74}$ or at least reject the actual certainty standard..$^{75}$ When, however, the fact of such loss or damages is established and the only question is their extent or amount, courts frequently have elaborated on the standard of proof. Some simply emphasize that reasonable certainty does not require absolute certainty ${ }^{76}$ but rather represents an "insistence that the trier of fact may not speculate or conjecture, but must instead have some factual basis for fixing damages." Courts often add that once at least some damage or the "fact of damage" is proved, proof of the extent of the damage is not required "with mathematical precision."" These statements are not facially inconsistent with the traditional more-likely-than-not standard of proof. Courts have sometimes gone further, however, and described the standard of proof somewhat differently. Thus, the Restatement suggests that once some loss is shown, its extent need not always be proved more likely than not; for some types of damages proof with "as much certainty as the nature of the tort and circumstances permit" will suffice. ${ }^{79}$ Some courts would profess to apply a more-likely-than-not standard of proof to estimates of partial losses and damages, possibly taking into account in some ill-defined way the damages evidence that was reasonably available. As a practical matter, many courts would only require sufficient proof, including expert testimony when needed, to allow a reasonably accurate estimate of the probable extent of the tort-based loss and damages, assuming the plaintiff made reasonable use of the available evidence. ${ }^{80}$

A few courts occasionally have gone further in relaxing the usual proof requirements. For example, in the New Jersey case of Betenbaugh v. Princeton Hospital, ${ }^{81}$ the plaintiff alleged that the defendant had negligently taken incomplete X-rays of a patient who had previously injured

74. See, e.g., Powell v. Montgomery, 27 Ohio App. 2d 112, 115-16, 272 N.E.2d 906, 909-910 (1971); Hargrove v. Peterson, 65 Wis. 2d 118, 125, 221 N.W.2d 875, 879-80 (1974); Blakeman v. Gopp, 364 P.2d 986, 992 (Wyo. 1961); C. MCCORMICK, HANDBOOK ON THE LAW OF DAMAGES $§ 26$ (1935). Many courts do not even mention the "reasonable certainty" language in discussing proof of damages, preferring instead to use the traditional (and less ambiguous) "more likely than not" language or a similar construct. See, e.g., Healy v. White, 173 Conn. 438, 444-45, 378 A.2d 540, 544 (1977) (using "reasonably probable" standard). It has been suggested that the "reasonable certainty" phrase may sometimes be regarded as a stricter standard than the "reasonably probable" language. Note, Awarding Damages for Permanent Injuries: A Proposal to Eliminate the Unreasonableness of "Reasonable Certainty" in Jordan v. Bero, 4 HOFSTRA L. REV. 101, 102 n.7 (1975). The trend appears to be toward confluence of the two formulations.

75. See, e.g, Lobred v. Mann, 395 S.W.2d 778, 781 (Ky. 1965); note 61 supra (citing cases).

76. See C. MCCORMICK, supra note $74, \S \S 26-27$.

77. D. DOBBS, supra note $56, \S 3.3$, at 151 .

78. Id.

79. Resthtement (SEcond) of TORTS $\S 912$ (1979); see id. Comment b.

80. See D. DoBBs, supra note $56, \S 3.3$, at 151,153 . Some types of damages, such as lost profits, may present special problems. See id. $\$ 8.1$, at 541-43.

81. 50 N.J. 390, 235 A.2d 889 (1967) (per curiam). For later developments in New Jersey, see p. 1391 infra. 
her back. The plaintiff further alleged that, as a result, treatment was delayed, with a concomitant delay in recovery and added suffering. Although there was expert testimony that the alleged negligence had produced some unnecessary pain and some postponement of recovery, apparently the extent of this additional harm was not explicitly addressed by the expert testimony or established by other evidence. Nevertheless, the record was held sufficient to entitle the plaintiff to reach the jury. ${ }^{82}$ Most courts, however, would require that evidence, including expert testimony when needed, afford a reasonable evidentiary basis for estimating the probable loss. ${ }^{83}$

\section{B. Reappraisal of the All-or-Nothing Concept of Chance}

Loss of a chance should be compensable even if the chance is not better than even, and it should be recognized and valued as such rather than as an all-or-nothing proposition. Any other rule fails to satisfy the goals of tort law.

\section{Compensating the Not-Better-Than-Even Chance}

The all-or-nothing approach to the loss of a chance is difficult to defend for a number of reasons. On a purely conceptual level, it is arbitrary. When one's claim is based on the destruction of a chance of avoiding some fairly definitive loss or on the creation of a chance of such a future loss, the all-or-nothing concept operates radically. A chance that does not rise to a level consonant with the applicable standard of proof counts for naught. This is only partly true for destruction of opportunities for avoiding less definitive or partial losses, as well as those damages questions that are subject to a similar analysis. Once at least some such partial losses or damages are established under the applicable standard of proof, the trier of fact must determine the extent of the loss. In answering this question by arriving at an estimate, chance is by definition integrated into the calculus. There are, however, no rational reasons for not also compensating the loss of a chance (however small) of avoiding some partial loss or a definitive loss.

An example illustrates the arbitrariness of this selective application of the all-or-nothing concept. Consider a jar containing pennies. Once the trier of fact finds that the jar probably contains at least some coins, its loss would be compensable under traditional rules, with its value reflecting an

82. 50 N.J. at $392-93,235$ A.2d at 890 .

83. See, e.g., Henderson v. Breesman, 77 Ariz. 256, 259, 269 P.2d 1059, 1061-62 (1954); Valley Nat'l Bank of Arizona v. Haney, 27 Ariz. App. 692, 694, 558 P.2d 720, 722 (1976); Powell v. Montgomery, 27 Ohio App. 2d 112, 115-23, 272 N.E.2d 906, 909-14 (1971). 
estimate of its contents. In this case it is estimated that the jar contains forty coins, and there is an identical chance that there are more or less than forty coins in the jar. The value of the jar of coins based on this estimate accordingly would be forty cents. Now consider the loss of a chance to draw one coin from a second jar containing one hundred coins, forty worth one dollar each and sixty that are valueless. There is a $40 \%$ chance that any one coin picked at random will be worth one dollar. The estimated value of a chance randomly to draw a coin from this jar is, then, forty cents. The possibility that the chance is worth more than forty cents is discounted by the identical chance that it is worth less than forty cents. The $40 \%$ chance is a final estimate, already discounted, just like the estimate of the value of the contents of the first jar. The decision to compensate the former estimate and not the latter makes no more sense than an arbitrary holding with respect to the first jar that its loss would not be compensated unless it was estimated to contain at least fifty-one coins.

The limited application of the all-or-nothing principle to the loss of a chance of avoiding a partial loss-requiring that the lost chance have been better than even-is also arbitrary. Assume that there are three jars, only one of which contains an estimated forty cents. Under the traditional rule, the loss of a one-in-three chance of selecting the jar with coins would not be compensated. It makes little sense, however, to compensate the estimate of the number of cents in the jar once it is established that one probably lost a jar with some coins, but to refuse to compensate the equally valid estimate of the chance of initially chosing the jar with the coins.

The all-or-nothing approach to loss of a chance also subverts the deterrence objectives of tort law by denying recovery for the effects of conduct that causes statistically demonstrable losses. By placing such losses outside tort law, the all-or-nothing approach distorts the loss-assigning role of that law. Over the universe of such cases, losses of chances of avoiding both the adverse effects of a preexisting condition and the occurrence of future consequences of an injury represent actual losses. We can be statistically certain, for example, that a number of patients with probably (but not necessarily) fatal preexisting conditions would have achieved the hoped-for cure in the absence of the tortious conduct, even if none individually had a better-than-even chance of doing so. A failure to allocate the cost of these losses to their tortious sources undermines the whole range of functions served by the causation-valuation process and strikes at the integrity of the torts system of loss allocation.

The injustice created by the all-or-nothing concept of chance also creates pressure to manipulate and distort other rules affecting causation and damages in an effort to mitigate this perceived harshness. Manipulation of the standard of proof represented by the substantial possibility test is a 
prime example. ${ }^{84}$ Such expedients not only threaten to subvert these other concepts, but also fail to solve the real problem of the all-or-nothing approach to the loss of a chance.

Destruction of a chance should also be compensated for reasons of fairness. But for the defendant's tortious conduct, it would not have been necessary to grapple with the imponderables of chance. Fate would have run its course. A defendant's tort not only destroys a "raffle ticket," in so doing it destroys any chance of ever knowing how that ticket would have fared in the drawing. Recognizing the destruction of a chance as a compensable interest valued as such would also offer the most administrable and consistent method for dealing with many complicated cases. ${ }^{85}$

On a more visceral level is the question whether one who loses a notbetter-than-even chance of achieving some favorable result, perhaps life, really loses nothing worthy of redress. The loss includes not only the thenexisting chance, but also the loss of the opportunity to benefit from potential scientific breakthroughs that could transform the chance into reality. From a psychological standpoint, there is a qualitative difference between a condition that affords a chance of recovery and one that offers no chance at all, as any patient with terminal cancer will confirm. This inherent worth of a chance is added reason for recognizing its loss as a compensable interest.

Some courts have recognized the compensability of the loss of a chance in the case of a contest. Obviously, when a chance to win a contest has a clearly defined market value-as in the case of a lottery ticket-there is little difficulty in viewing the chance as an asset. ${ }^{86}$ It would be absurd to say that a one dollar lottery ticket had no value merely because the prospects of winning with it were not better than even.

The right to recover has also been recognized in some contest cases when no clear market value for the chance had been established. In Mange v. Unicorn Press, ${ }^{87}$ for example, the plaintiff sued the defendant-

84. See pp. 1368-69 supra.

85. Take, for example, a case involving a negligent delay in the diagnosis of cancer. Assume that by the time the disease was diagnosed, the plaintiff had only a $35 \%$ chance of recovering from it. Assume further that with timely diagnosis the plaintiff would have had an $80 \%$ chance of a full recovery. On the one hand, it appears more likely than not that the plaintiff will not survive. It also appears that if death ensues, it will probably be a result of negligence. On the other hand, the probability that the plaintiff not only will not survive, but will not survive because of the defendant's negligence is only $45 \%$ ( $80 \%$ minus $35 \%$ ), because that is the extent to which the negligent omission has increased the probability of death. This would probably mean that the lost chance was not then compensable under the traditional rule. The confusion on this issue would be avoided if the "injury" is considered to be the loss a $45 \%$ chance of cure. If the victim actually died of cancer, the plaintiff would probably prevail under the traditional rule, and the loss under the suggested approach would increase because it would then be clear from the facts that the victim was not within the $35 \%$ chance of survival.

86. See D. DOBBS, supra note $56, \S 3.3$, at $156-57$.

87. 129 F. Supp. 727 (S.D.N.Y. 1955). 
encyclopedia publisher for breach of contract on the ground that he was deprived of a chance to win a puzzle contest. The plaintiff had marked a statement as "wrong" because the spelling of a word did not correspond to the spelling contained in the encyclopedia that was, under the contest rules, the controlling authority. If the plaintiff's answer had not been disqualified, he would have been one of 23,548 contestants to compete for 210 prizes, including a $\$ 307,500$ first prize. In response to the defendant's argument that an award of actual damages would be too speculative, the court said:

[A]lthough there is substantial authority denying recovery . . . there appears to be a liberal trend towards allowing the jury to determine the value of the chance of which plaintiff was deprived .... The rationale behind these cases is that plaintiff's chances of success would have had some market value especially since there was no risk of out-of-pocket loss offsetting the possibility of gain. ${ }^{88}$

Although the preponderance of the early decisions seemed to reject the compensability of losses of a not-better-than-even chance of a single specific gain, ${ }^{89}$ a few subsequent cases imply a more liberal attitude toward such claims. ${ }^{90} \mathrm{~A}$ number of commentators favor recovery in such cases, ${ }^{91}$ at

88. Id. at 730 .

In the famous English case of Chaplin v. Hicks, [1911] 2 K.B. 786 (C.A.) the defendant was a theatrical manager who conducted a contest to select twelve beautiful women. The prize for each was employment on stage for three years at varying pay scales. An initial group of fifty contestants was to be selected. The plaintiff was chosen as one of the fifty semi-finalists, but because of the defendant's failure to notify her in time, she did not appear for the final selection. The plaintiff instituted an action for breach of contract. The Court of Appeal affirmed a judgment for the plaintiff awarding damages to reflect the value of the lost chance of her being selected as one of the twelve winners. Although the court recognized that each of the fifty finalists' chance of being selected was only about one in four (thus not better than even), it nevertheless held that such a chance was worthy of redress.

A similar case is that of Kansas City, M. \& O. Ry. v. Bell, 197 S.W. 322 (Tex. Civ. App. 1917). In Bell, the plaintiff claimed that but for a delay in the shipment of his hogs, he would have won first rather than second prize at the Fort Worth Stock Show. The court seemed to approve the idea that loss of the chance itself was compensable, saying:

The chance might be worth little or nothing, or it might be worth, under some circumstances,

the full amount of the premium offered for the best of the class in which plaintiff was to be a competitor. In such a case, evidence as to all such matters as would tend to show the probability that the plaintiff would be successful in the competition would be admissible, and ... it would then be left to the good sense of the jury trying the case to determine the value of the plaintifl's chance in the competition.

Id. at 323. This language seems to suggest that the chance itself, even apart from its materialization, would be compensable. Furthermore, the court seemed to contemplate a measure of compensation that would reflect the probabilities of the chance's realization. There is disagreement among the commentators as to this interpretation, however. Compare C. MCCORMICK, supra note $74, \S 31$, at 122-23 (agreeing with preceding interpretation) with D. DOBBS, supra note $56, \S 3.3$, at 156 n.35 (disagrecing).

89. See C. MCCORMICK, supra note 74, § 31, at 122.

90. See id. at 122-23.

91. See, e.g., id. 
least when there is some rational basis for assigning value to the chance.92 There has been surprisingly little express analysis of one's right to recover for the loss of a not-better-than-even chance valued as such in personal injury tort cases. ${ }^{93}$ The traditional rule in many respects not only treats chance in all-or-nothing terms but, under the prevailing view, denies recovery for not-better-than-even chances. ${ }^{94}$ Nevertheless, a few cases seem, with varying degrees of equivocation, to recognize such chances as compensable interests in their own right free of the all-or-nothing perturbation. ${ }^{95}$ In addition, there has been some recent support for compensating the not-better-than-even chance valued as such in the future consequences context when such recovery would be denied under traditional rules. ${ }^{96}$

92. See D. DOBBS, supra note $56, \S 3.3$, at $156-57$.

93. There has been scant attention in the legal literature to the place of chance in personal injury litigation. When the question has been considered, however, the commentators almost uniformly have favored treating the loss of a chance of avoiding some adverse result as a compensable interest in its own right, at least in some factual settings. See, e.g., P. ATIYAH, ACCIDENTS, COMPENSATION AND THE LAW 114-15 (2d ed. 1975); A. BECHT \& F. MILlER, supra note 3, at 122-30; J. STEIN, supra note 67, $\S 106$, at 183-84; Green, The Causal Relation Issue in Negligence Law, 60 MICH. L. REV. 543, 558-59 (1962); Malone, supra note 5, at 80-81. A number of commentators have, to varying degrees, advocated recognizing chance as a compensable interest for the law of damages in general. See, e.g., C. MCCORMICK, supra note 74, § 31, at 122-23; Schaefer, Uncertainty and the Law of Damages, 19 WM. \& MARY L. REV. 719, 762 (1978); Note, Damages Contingent Upon Chance, 18 RUTGERS L. REV. 875, 892-94 (1964).

94. See pp. 1364-76 supra.

95. See O'Brien v. Stover, 443 F.2d 1013, 1019 (8th Cir. 1971); James v. United States, 483 F. Supp. 581, 585-86 (N.D. Cal. 1980); Bellaire Gen. Hosp., Inc. v. Campbell, 510 S.W.2d 94, 98 (Tex. Civ. App. 1974). None of the foregoing cases represents unequivocal support for compensating the not-better-than-even chance. In O'Brien, the court merely suggested that loss of a chance of survival should in some undefined way be included in the damages equation. $443 \mathrm{~F} .2 \mathrm{~d}$ at 1019 . It did not expressly acknowledge that the chance was not better than even (although the expert testimony did not suggest otherwise). O'Brien applied Iowa law, and a later Iowa case apparently retained an allor-nothing view of loss of a chance. See Speed v. State, 240 N.W.2d 901, 906 (Iowa 1976).

In James, the plaintiff contended that the defendant's allegedly negligent failure to inform him of a suspected tumor destroyed a $10 \%$ to $15 \%$ chance of long-term survival that would have existed if the tumor had been operable. The court refused to allow recovery for the loss because it did not appear probable that the tumor had been operable at the time. The court implied that had the existence of that chance been established, it would have been compensable, although it is unclear whether the court would have valued the chance as such or treated it as an all-or-nothing matter under the substantial possibility rule, see note 53 supra. The court did, however, allow recovery for loss of a chance of prolonging life or decreasing suffering, "[n]o matter how small that chance may have been." $483 \mathrm{~F}$. Supp. at 587.

In Bellaire, the jury found that oxygen deprivation, for which the hospital was responsible, caused the death of the patient. The court implied that damages would include the loss of a chance of recovery from the preexisting condition even if that chance were "remote." 510 S.W.2d at 98. A more recent Texas case, however, seemed to reject that view, at least in the passive injury context. See Lee v. Andrews, 545 S.W.2d 238, 244 (Tex. Civ. App. 1976) (must appear that, but for failure to diagnose condition, patient probably would have survived).

96. In Feist v. Sears, Roebuck \& Co., 267 Or. 402, 517 P.2d 675 (1973), a child suffered a skull fracture and sought recovery based on the possibility that he might some day contract meningitis. Since the expert testimony indicated only a possibility of future meningitis, the court refused to allow recovery for actual future eventuation of the meningitis. Nevertheless, the court held that the jury's award could reflect the added "susceptibility" to meningitis. Id. at 413,517 P.2d at 680 . The rule was extended to allow recovery for a $30-45 \%$ possibility of the need for future surgery. See Pelcha v. United Amusement Co., 44 Or. App. 675, 606 P.2d 1168 (1980). 
Damages for mental distress associated with an injury have been awarded to compensate plaintiffs for fear of future consequences even though proof was insufficient to support recovery for the materialization of those consequences. ${ }^{97}$ Although these subjective damages are hardly the answer to the chance problem, they tend to underscore the reality of chance in the future consequences context.

Quite recently, the California Supreme Court held that liability could sometimes be based on and reflect the chance that a defendant was the manufacturer of the injury-producing drug. The court held that under the particular circumstances of this case, each defendant-manufacturer could be held liable for the proportion of the judgment represented by its share of the relevant market unless it demonstrated that it could not have made the injuring product. ${ }^{98}$ Although the case involved problems of causation rather than the matter of valuation of a lost chance, ${ }^{99}$ and although the decision was a narrow one, it nevertheless is an important signal of the increased willingness of courts to integrate chance into its resolution of torts cases.

In summary, the all-or-nothing approach to the loss of a chance irrationally and unfairly denies the reality of chance as an appropriately cognizable interest in the torts system. It also undermines the loss-assigning function of tort law by improperly externalizing significant costs of various enterprises.

\section{The Process of Valuing Chance}

If one accepts the premise that chance is itself an interest worthy of redress, one must develop an appropriate method of assigning a value to a particular lost chance. A number of methods of valuing chance are possible. Most courts that have recognized chance as a compensable interest have allowed the trier of fact to value chance without offering meaningful

One judge in a tort case persuasively argued:

[R]equiring a man to stand in the arena and open one of two doors [one housing a tiger] is in and of itself a separate injury. The fact that a person is confronted with a ten percent, fifteen percent, or twenty percent probability (in the mathematical sense) that he will suffer future injuries should be sufficient to permit him to recover for those future injuries at least in proportion to the probability of such injuries occurring.

Jordan v. Bero, 210 S.E.2d 618, 640-41 (W. Va. 1974) (Neely, J., concurring).

97. See, e.g., Figlar v. Gordon, 133 Conn. 577, 585, 53 A.2d 645, 648 (1947); Anderson v. Welding Testing Lab., Inc., 304 So. 2d 351, 353 (La. 1974); Smith v. Boston \& M.R.R., 87 N.H. 246, 258-59, 177 A. 729, 738-39 (1935); Ferrara v. Galluchio, 5 N.Y.2d 16, 20-22, 152 N.E.2d 249, 25253, 176 N.Y.S.2d 996, 999-1000 (1958). But see Howard v. Mt. Sinai Hosp., Inc., 63 Wis. 2d 515, 519, 217 N.W.2d 383, 385 (1974) (fear of cancer). See generally W. ProssER, supra note 3, § 54, at 327-33.

98. Sindell v. Abbott Laboratories, 26 Cal. 3d 588, 610-13, 607 P.2d 924, 936-38, 163 Cal. Rptr. 132, 144-46, cert. denied, 101 S. Ct. 286 (1980) (discussed in note 116 infra).

99. For a brief discussion of possible application of a chance-valuation mathematical analysis to issues outside of the valuation inquiry, see Pp. 1394-96 infra. 
guidance on how to do so. This method has the advantage of simplicity and, to the extent that it rests on the jury's common sense, may be compatible with the goals of substantial justice. Nevertheless, an important reason for compensating the loss of a chance is to achieve a more accurate loss allocation. This being so, a more predictable and finely tuned method of valuation is preferable.

A better method of valuation would measure a compensable chance as the percentage probability by which the defendant's tortious conduct diminished the likelihood of achieving some more favorable outcome. Under this approach, the trier of fact would continue to make the valuation, but would do so within specific guidelines and parameters set by the court.

To illustrate, consider a patient who suffers a heart attack and dies as a result. Assume that the defendant-physician negligently misdiagnosed the patient's condition, but that the patient would have had only a $40 \%$ chance of survival even with a timely diagnosis and proper care. Regardless of whether it could be said that the defendant caused the decedent's death, he caused the loss of a chance, and that chance-interest should be completely redressed in its own right. ${ }^{100}$ Under the proposed rule, the plaintiff's compensation for the loss of the victim's chance of surviving the heart attack would be $40 \%$ of the compensable value of the victim's life had he survived (including what his earning capacity would otherwise have been in the years following death). The value placed on the patient's life would reflect such factors as his age, health, and earning potential, including the fact that he had suffered the heart attack and the assumption that he had survived it. The $40 \%$ computation would be applied to that base figure.

In many cases, a plaintiff may claim damages for the destruction of a chance of avoiding both definitive and partial losses. For example, assume that a cancer patient is negligently killed by an overdose of medication. Assume further that he had a $40 \%$ chance of recovery and that if he had recovered he would have lived an estimated thirty-five years. Even if he had not recovered from the disease, assume that he would have lived an estimated six months. The plaintiff would claim not only that the decedent was deprived of an opportunity of making a full recovery, but also that he probably lost six months of life even if the disease would have been fatal. Compensation should be calculated in a way that avoids double recovery for the same injury. The plaintiff would be compensated for the

100. How this proposal for compensating lost chances would operate under the statutes and rules governing tort actions in which the victim has died raises a host of questions that are beyond the scope of this article. Some modification of these statutes and rules might be necessary to accommodate the proposals made here in the type of situation described. See RESTATEMENT (SECOND) OF TORTS §§ 925-926 (1979). 
full value of the six months by which the decedent's life was probably shortened even if his cancer had been incurable. To this amount would be added the value of the chance of living beyond the six months. Thus, we would add $40 \%$ of the value of thirty-four and one-half years of the decedent's life (thirty-five years minus the six months already covered by the acceleration damages) to the full value of the loss of six months of life. ${ }^{101}$

The application of the percentage probability test may be more complicated in many situations in which the value of the lost chance depends on predicting or postulating future events. A plaintiff may claim that the defendant's tort destroyed a chance of avoiding an untoward future development, such as blindness. The plaintiff's ultimate claim may include the loss of some future benefits such as future earnings. Thus, the valuing of a lost chance may require an appraisal and integration of the prospects that a physical condition will develop, the offsetting likelihood that it would have developed independent of the tort, and the prospects that the victim would otherwise have received earnings. Valuing these interrelated chances to arrive at a value of the lost compensable chance is complicated because each of the interrelated chances often may depend on a number of possible scenarios.

One could apply the percentage probability test in either of two ways. Consider its application to a tortious accident to a twenty-year old plaintiff that creates a chance that blindness will result in the future. One approach, which might be termed a "single outcome" approach, would involve two stages. Initially, the trier of fact would determine the most likely time of onset of blindness. Assume that if blindness does result in the future, the most likely age of onset for this particular plaintiff would be age fifty. Assume further that if blindness does occur at fifty, the loss attributable to that condition would be $\$ 100,000$. Because, however, it is not certain that the injury will result in blindness, it would not be appropriate to award the full $\$ 100,000$. If the probability that the injury will result in blindness at any time is $30 \%$, one might value the chance at $\$ 30,000 .^{102}$

101. An expected value computation might also be used to measure the effects of preexisting conditions on liability for future consequences in this example. See p. 1384 infra.

102. What I have termed the "single outcome" method of applying the percentage probability test has seldom been articulated as such in the cases. The opinion that probably comes closest to adopting this test is a concurring opinion in a fairly recent West Virginia case. See Jordan v. Bero, 210 S.E.2d 618, 640-41 (W. Va. 1974) (Neely, J., concurring). Under that opinion's recommended approach, not only would chance be deemed a compensable interest, but its value would reflect its probability of occurrence. Accordingly, Justice Neely made the following suggestion:

[T] he jury would be instructed that from all the evidence they should determine [usually with the aid of expert testimony] what the overall probability is that the plaintiff will suffer future damages, and that from all the evidence they should determine the amount of monetary damages to which the plaintiff would be entitled if the disabilities which doctors reasonably believe are possible actually come to pass. The jury would then be instructed to multiply the amount of future damages reasonably to be expected times the probability of those damages actually 
A second and more precise method of applying the percentage probability test involves application of an "expected value"103 or "weighted mean" computation. This process would require computing a "weighted average of all the possible outcomes, the weight assigned to each outcome being determined by the likelihood of its occurrence."104 Elaborating on the preceding example, assume, in an admittedly oversimplified set of facts, that as a result of the accident there is a $25 \%$ chance of the onset of injury-induced blindness occurring at fifty years of age, a $4 \%$ chance at forty, a $1 \%$ chance at thirty, and a $70 \%$ chance that such blindness would never result. Assume further that these are the only possible outcomes. Finally, assume that if blindness occurs at age fifty the loss would be $\$ 100,000$; if at age forty, $\$ 200,000$; and if at age thirty, $\$ 300,000$. Under the expected-value approach, the chance would be valued by aggregating the possible outcomes discounted to reflect their degree of likelihood. Thus, we would add $\$ 25,000$ (25\% of $\$ 100,000), \$ 8,000$ (4\% of $\$ 200,000), \$ 3,000$ (1\% of $\$ 300,000)$, and $\$ 0(70 \%$ of $\$ 0)$, giving a total value of the chance of injury-induced blindness of $\$ 36,000$. In this example, the expected-value method produced a higher damage figure than the single-outcome test. Under a different set of probabilities, however, the opposite might be true. The difference can be pronounced, especially as the prospects of occurrence of an adverse consequence approach $100 \% .{ }^{105}$

Each of the percentage methods of valuation has advantages and drawbacks. The single-outcome method is less complex and requires fewer computations. The expected-value construct could involve a virtually unlimited number of permutations that would have to be weighted before they could be aggregated to arrive at the value of the chance. The real advantage of the expected-value method, however, is that it more precisely measures the value of a chance. The single-result method is subject to some of the criticisms leveled at the all-or-nothing view of chance. While valuing the most likely chance, other less likely chances are not accurately valued except by generally discounting the most likely chance to reflect the probability of any occurrence. The expected-value method therefore is more consonant with a central purpose of valuing chance: achieving a more rational and accurate loss allocation. Moreover, the administrative

occurring and arrive at a figure which will compensate the plaintiff for the possibility of future injuries.

Id. at 641 . One commentator has interpreted the opinion as suggesting an "expected value" method of computation. See Schaefer, supra note 93, at 746. Justice Neely's language, however, appears to come much closer to the "single outcome" method of valuation.

103. See Schaefer, supra note 93, at 722 .

104. Id. For an explanation of expected value, see P. HOEL, ELEMENTARY STATISTICS 90-94 (4th ed. 1976).

105. Recovery for future consequences should, under either approach, be reduced to present value to the extent required by damages rules. See note 56 supra. 
problems associated with this method are surmountable. ${ }^{106}$

The presence of a preexisting condition may add an additional factor to the valuation process in claims for future consequences. That a preexisting condition has created a chance of future losses should be taken into account in assessing the loss for which the defendant is held responsible. ${ }^{107}$

On its face, the proposed percentage rule may appear to be a relatively complex method for valuing chance. Yet similar determinations are required constantly even under the traditional rules. How else, for example, do we even know whether we are talking about a better-than-even chance when applying the all-or-nothing rule? Professor Tribe, who has expressed reservations about excessive use of mathematics in trials, has conceded that all factual evidence is ultimately statistical and probabilistic in the epistemological sense. ${ }^{108}$ Moreover, even if, as a general matter, there is some truth in Tribe's conclusion that "the costs of attempting to integrate mathematics into the factfinding process of a legal trial outweigh the benefits," 109 the use of probabilistic analysis in the limited context of loss valuation appears not only warranted, but essential, if chance is to be deemed a compensable interest. Especially if one considers the alternatives either of affording no meaningful guidance to the trier of fact or, even worse, of retaining the all-or-nothing approach to loss of a chance, the proposed percentage rule appears both workable and advantageous. As Professor Kaye correctly suggests, the only real question should be "whether the [probability] technique would reduce the number of errors in factfinding." "110 The methodology postulated here demonstrably would.

106. Administrative problems that inhere in the potentially infinite number of future possible outcomes can be substantially alleviated by limiting the number of possible outcomes through grouping. Thus, rather than engaging in a surrealistic exercise of weighing the value of the chance of something transpiring at each hour, minute, or second of the victim's future, possibilities could be consolidated. For example, the chance of future blindness could be valued by dividing the life expectancy of the plaintiff into one-year segments. The loss from blindness occurring during each segment could be estimated by computing the loss for the most likely moment of onset during that segment. That loss could then be discounted to reflect the likelihood of occurrence at any time during that segment. Finally, the value for these weighted risks of all segments would be aggregated to form the expected value of the chance. This procedure, accordingly, would draw upon the expected value method for the final computation, but would employ a single outcome analysis within each segment. The creative use of expert witnesses to assist the trier of fact should also considerably facilitate the valuation process.

107. Thus, assume that a tortious head injury creates a $40 \%$ chance of the victim developing epilepsy at a specified age. Assume also that because of a preexisting condition the victim already had a $20 \%$ chance of developing the disease. The plaintiff would be compensated for the extent to which the tort, by creating a $40 \%$ chance of epilepsy, increased the existing risk and in so doing reduced the $80 \%$ chance of avoiding the disease.

Preexisting conditions not relating to the same bodily consequences to which the tort relates should also be taken into account.

108. Tribe, Trial by Mathematics: Precision and Ritual in the Legal Process, 84 HARV. L. REV. 1329,1330 n.2 (1971).

109. Id. at 1377.

110. Kaye, The Laws of Probability and the Law of the Land, 47 U. CHI. L. REV. 34, 36 (1979). 
As a purely technical matter, valuing chance appears to be well within the competency of science. ${ }^{111}$ The probability of a lost chance can be derived in a number of ways. One may deduce the probability figure from so-called "relative frequency"112 by looking at the way in which the same or similar forces operated in the past. Even when hard empirical data from which to extrapolate a percentage valuation of a chance is not available, other estimating methodologies may be used. One might use the personalistic theory for estimating probability, ${ }^{113}$ in which the trier of fact is presented with a hypothetical gambling situation and is offered a hypothetical reward for making a correct choice among possibilities. ${ }^{14}$ This process can be refined quantifiably by asking the trier of fact a series of questions-for example, whether he would prefer either betting on the existence of a given fact or taking a chance on selecting a specific card or category of card from a deck. ${ }^{115}$ By extrapolating from the known probabilities of selecting the card and the preferences of the trier of fact, we arrive at an estimate of the probability of a given event. ${ }^{116}$

111. Medical science, for example, has become skilled in predicting the probabilities of survival for various diseases and traumatic injuries. See, e.g., Bruce, Gennarelli, \& Langfitt, Resuscitation from Coma Due to Head Injury, 6 CRITICAL CARE MED. 254 (1978); Shapiro, The Evaluation of Clinical Predictions, 296 NEW ENG. J. MED. 1509 (1977). More accurate methods for analyzing risk factors generally have also been developed. See, e.g., Miettinen, Standardization of Risk Ratios, 96 AM. J. EPIDEMIOLOGY 383 (1972); Walter, Calculation of Attributable Risks from Epidemiological Data, 7 INT'L. J. EPIDEMIOLOGY 175 (1978).

112. Iversen, Operationalizing the Concept of Probability in Legal-Social Science Research, 5 LAW \& SOC'Y REV. 331, 331 (1971). Iversen illustrates relative frequency as follows:

[I] $n$ coin tossing, to find the probability of a coin coming up heads $I$ toss the coin $n$ times and observe that $x$ of those tosses produce heads. The relative frequency of heads is $x / n$, and when Id.

$\mathrm{n}$ increases to infinity this relative frequency equals the probability of heads.

113. See Kaplan, Decision Theory and the Factfinding Process, 20 STAN. L. REv. 1065, 1066-67

(1968); Tribe, supra note 108 , at 1347-49.

114. See Kaplan, supra note 113 , at 1067.

115. See id.; Wagner, Book Review, 1979 DUKE L.J. 1071, 1072 n.6 (reviewing L.J. COHEN, The Probable and THe Provıble (1977)).

116. Courts have, in recent years, shown increased willingness to apply mathematical percentage computations to resolve difficult legal dilemmas in personal injury litigation. In Sindell v. Abbott Laboratories, 26 Cal. 3d 588, 607 P.2d 924, 163 Cal. Rptr. 132, cert. denied, 101 S. Ct. 286 (1980), for example, the plaintiff sought damages for injuries allegedly resulting from consumption by her mother of the miscarriage-preventing drug "DES." The drug was found to cause vaginal cancer in daughters whose mothers had taken DES before giving birth. Unfortunately, the plaintiff was unable to establish which manufacturer was the source of the DES taken by her mother. Nevertheless, the court held that because the drug was manufactured from a single formula, because the plaintiff through no fault of her own was unable to identify the source, and because the plaintiff joined as defendants in the action the manufacturers of a substantial share of the DES that her mother may have taken, each defendant would be subject to liability for the proportion of the judgment reflecting its percentage share of the relevant product market, unless it demonstrated that it could not have made the dose that caused the plaintiff's injuries. Id. at 611-13, 607 P.2d at 937, $163 \mathrm{Cal}$. Rptr. at 145. The kind of proportional mathematical computation envisioned in Sindell, although dealing with causation rather than valuation, and based on what is perhaps more readily quantifiable data, involved a process similar to that required to allocate responsibility between a preexisting condition and a tortious injury, and to value the loss of a chance. 
In short, valuing chance is feasible. Moreover, in spite of its unavoidable inexactness, the compensation of lost chances will introduce a substantially higher level of precision and, therefore, validity into the loss-assigning process. As one commentator aptly noted, "[t] ime impossibility of absolute certainty does not mean that we cannot make our factfinding apparatus substantially better than it is."117

\section{Better-Than-Even Chances}

The percentage probability test has thus far been discussed as an answer to the problem of the loss of a not-better-than-even chance of some favorable result and the creation of a not-better-than-even chance of future consequences. Once we accept the notion that chance is itself an interest entitled to redress and that chance should be measured by a mathematical percentage probability test, we are faced with the question whether that same method of valuation should also be applied to betterthan-even chances as well.

Under the prevailing all-or-nothing rule, most courts probably would value the better-than-even chance as though it had materialized or were certain to do so. They would not, in other words, treat such a chance as a chance at all, but as a certainty. ${ }^{118}$ To illustrate, assume that a patient died from a ruptured appendix that was negligently misdiagnosed. Assume further that the patient would have had a $95 \%$ chance of survival with timely diagnosis and treatment. In figuring damages in such a case most courts, applying the all-or-nothing concept, would award damages based on $100 \%$ of the value that the decedent's life would have had if he had recovered from his appendicitis.

This result is as questionable as the extreme reached when the all-ornothing concept denies any redress for the destruction of a not-betterthan-even chance. By compensating the $95 \%$ chance as though it were $100 \%$, courts overcompensate the plaintiff. Both types of chance should be valued in a way that reflects their probability of occurrence. Such an approach would also promote a more accurate loss allocation.

\section{G. A Note on Conjunction}

The outcome of both the causation and valuation inquiries may often depend on a number of constituent factual premises. An important ques-

117. Kaplan, supra note 113, at 1071.

118. Thus, loss of a better-than-even chance of avoiding a definitive or some partial loss would not be discounted by the chance that the loss would have occurred in any event. In estimating the extent of the partial loss suffered and damages generally for both types of losses, however, the chance that a greater or lesser loss had been or will be suffered would, under the traditional rules, be integrated into the estimation. See pp. 1373-76 supra. 
tion is whether the probability of these constituent premises should be conjoined or should be treated independently in determining whether the standard of proof is satisfied. If the constituent probabilities are conjoined, the plaintiff's burden ${ }^{119}$ is increased exponentially, because "mathematical probability obeys a multiplicative conjunctive principle, whereby the probability that two independent events both occur is equal to the mathematical product of their individual probabilities." 120 Thus, the probability of throwing an ace with a single die is one in six; the probability of throwing two aces with a simultaneous throw of two dice is one in thirtysix. ${ }^{121}$ A similar principle determines the probability of two conclusions that are to some extent interdependent: "the probability that both of two events will occur is equal to the probability that the first event will occur, multiplied by the conditional probability that the second event will occur when it is known that the first event [has occurred or] is certain to occur." 122

A plaintiff may allege, for example, that the defendant's uninsulated wires caused the victim's death. It might appear that there was a $60 \%$ probability that the victim was electrocuted by a live wire and a $60 \%$ probability that, if by a wire, then by the defendant's wire. ${ }^{123}$ Applying the conjunctive principle to this illustration, we find that the probability that the defendant's wire caused the death was $36 \%$ (60\% x 60\%). This probability would not satisfy the traditional more-likely-than-not standard of proof. If, however, each constituent factual premise were addressed in isolation, each individually would appear more likely than not. Thus, the decision whether to apply the conjunction principle might well determine the outcome of the causation question. Most courts, if forced explicitly to confront the question, would probably opt for the conjunction principle on the causation question: authorities generally state the standard of proof on the causation element in terms of proving that the ultimate fact of causation, rather than each constituent fact, was more likely than not. ${ }^{124}$

119. This assumes, arguendo, that the burden of proof remains on the plaintiff. See generally pp. 1390-94 infra.

120. L.J. Cohen, The Probable and the Provable $51-52$ (1977).

121. See P. LAPlace, A PHILOSOPhichl Essiy on Probabilities 12-13 (6th French ed. F. Truscott \& F. Emory trans. 1902).

122. P. HOEL, supra note 104 , at 51 . Thus, if the probability of $A$ is $40 \%$, and the probability of $B$ is $60 \%$ if A occurs, then the probability of A and B would be $24 \%$ (the product of $40 \%$ and $60 \%$ ).

123. For present purposes, these hypothetical percentages should be deemed to represent syntheses of all relevant evidence on the particular point. Thus, the instant analysis should not be taken as addressing the different matter of the use of pure statistical and mathematical evidence in trials. Compare Kaye, supra note 110, with Tribe, supra note 108. Use of relevant statistical data, however, should be an important part of the valuation process. See pp. 1381-87 supra.

124. The Restatement, for example, states: "It is enough that [the plaintiff] introduces cvidence from which reasonable men may conclude that it is more probable that the event was caused by the defendant than that it was not." RESTATEMENT (SECOND) OF TORTS § 433B, Comment b (1965). Wigmore speaks generally of the burden of proving those "propositions . . . which are a prerequisite" 
The question of the applicability of the conjunction principle also arises with respect to valuation. Although courts will often acknowledge that there are many phases to the valuation inquiry, they seldom explain how the different variables affecting the value of a chance interrelate, or whether the conjunction principle should apply. Since most courts require that the lost chance of the favorable outcome have been more likely than not to have occurred absent the tort, they apparently would apply the conjunction principle to the valuation inquiry. ${ }^{125}$ The conjunction principle should be an indispensable feature of the valuation process. Admittedly, the principle tends to compound the harshness of the all-or-nothing approach. The solution, however, lies not in an abandonment of the conjunction principle, but in rejection of the irrational all-or-nothing approach to loss of a chance. Consider a victim suffering from preexisting cancer who is killed in an accident. If there was a $60 \%$ probability that the cancer would otherwise have been diagnosed when the cure rate would have been $70 \%$, the loss of a chance of a cure should be valued at $42 \%$ of the value of the life of the victim as cured.

While the conjunction principle should apply within the causation inquiry and within the probabilities in the valuation inquiry, it should not apply between them, given the current state of the law. As has already been argued, causation and valuation are analytically different concepts. The causation inquiry determines whether a defendant should be required to compensate a plaintiff for a loss. The valuation inquiry determines how much compensation is required. Application of the conjunction principle between causation and valuation would be impossible if causation contin-

to a party's right of action. $9 \mathrm{~J}$. WIGMORE, A TREATISE ON THE ANGLO-AMERICAN SYSTEM OF EVIDENCE $\S 2485$, at 272-73 (1940).

Both sides of the debate over the extent to which an inference may be based on an inference seem implicitly to support the conjunction principle. See generally id. at $\$ 41 ; 2$ F. HARPER \& F. JAMES, supra note $3, \S 19.4$, at 1071 . Since restrictions on inference-to-inference reasoning may be even more restrictive than the conjunction principle, those favoring such a restriction would necessarily prefer the conjunction principle over a nonconjunction approach. Those rejecting arbitrary limits on inferenceto-inference reasoning would find the conjunction principle a logical alternative.

125. This is true of the cases cited in note $\mathbf{4 5}$ supra. When the conjunction principle is impliedly rejected, the reason for the rejection may be a desire to avoid the harshness of the all-or-nothing approach to loss of a chance. In Speed v. State, 240 N.W.2d 901 (Iowa 1976), the plaintiff alleged that the defendant's negligence caused him to become blind. The Iowa Supreme Court found that reasonable men could differ on the causation (valuation) question. The court perceived the issue in terms of whether proper and prompt examination and tests probably would have discovered the plaintiff's condition, whether that discovery probably would have led to prompt treatment, and, if the treatment had been proper, whether it probably would have prevented the patient's blindness. Id. at 905-07. Thus, the court implicitly suggested that it would be sufficient for the standard of proof to be satisfied for each individual step, regardless of whether it was probable that absent the alleged negligence the blindness would have been averted.

There are two basic fallacies in the Speed case. First, implicit in the court's approach is approval of the all-or-nothing attitude to loss of a chance. The real question should have been what the lost chance of avoiding blindness was worth. The second fallacy is the apparent failure of the court to employ the conjunction principle. 
ued to be handled as an all-or-nothing proposition, but valuation were derived from a percentage probability analysis, as this article urges. If the all-or-nothing approach were retained for valuing the loss of a chance, causation and valuation could be conjunctively melded, but to do so would simply compound the injustice and irrationality of the all-or-nothing method. If, on the other hand, the percentage probability analysis were not only adopted for valuation purposes, but also extended to causation, a question beyond the scope of the present article, ${ }^{126}$ the conjunction principle could feasibly be applied between the concepts of causation and valuation.

\section{Burden of Proof}

In torts cases, the burden of proof ${ }^{127}$ on causation ${ }^{128}$ and valuation ${ }^{129}$ questions has, in general, been placed on the plaintiff. Generalization about the burden of proof in the context of preexisting conditions, however, is more difficult because of a failure of the courts adequately to distinguish and separate causation and valuation.

Once a preexisting condition has been established, it is necessary to determine who must prove the effect of this preexisting condition on causation and valuation. Except to the extent noted below, the plaintiff would ordinarily be required to prove the cause and extent of the total loss. When a tortious aggravation or acceleration of (or perhaps other injury in addition to) a preexisting condition of innocent origin has caused some loss, the cases are divided on who must prove how much of the total loss arising in that context is attributable to the tort. While the traditional view left this burden on the plaintiff, ${ }^{130}$ there has been growing support for shifting that burden to the defendant for both actively ${ }^{131}$ and passively caused injuries. The application of this approach in the passive injury context, when the question was how much harm was reasonably avoida-

126. See pp. $1394-96$ infra.

127. See generally C. MCCORMICK, supra note $42, \S 336$.

128. See RESTATEMENT (SECOND) OF TORTS § 433B(I) (1965). The Restatement shifts the burden in two situations. See id. $\S 433 \mathrm{~B}(2)-(3)$.

129. See D. DoBBS, supra note $56, \S 3.3$, at $150, \S 3.7$ at 189.

130. See, e.g., Henry v. Landreth, 254 Ark. 483, 486, 494 S.W.2d 114, 117 (1973); Walters v. Smith, 222 Md. 62, 65-66, 158 A.2d 619, 620-21 (1960); Valliere v. Filfalt, 110 N.H. 331, 333, 266 A.2d 843, 845 (1970); Morris v. Rogers, 80 N.M. 389, 390-91, 456 P.2d 863, 864-65 (1969); Howell v. Nichols, 22 N.C. App. 741, 743-44, 207 S.E.2d 768, 770-71, cert. denied, 286 N.C. 2ll, 209 S.E.2d 316 (1974).

131. See, e.g., Steinhauser v. Hertz Corp., 421 F.2d 1169, 1172-74 (2d Cir. 1970) (by implication); Stephens v. Koch, 192 Colo. 531, 533-34, 561 P.2d 333, 334 (1977); Matsumoto v. Kaku, 52 Hawaii 629, 630-34, 484 P.2d 147, 149-51 (1971) (by implication); Blaine v. Byers, 9I Idaho 665, 67274, 429 P.2d 397, 404-06 (1967); Becker v. D \& E Distrib. Co., 247 N.W.2d 727, 729-30 (Iowa 1976). 
ble, is illustrated in Fosgate v. Corona. ${ }^{132}$ The plaintiff in Fosgate sued the defendant-doctor for failing to diagnose the patient's long-standing tuberculosis. The New Jersey Supreme Court, noting the difficulty of separating the harm, held that the defendant had the "burden of segregating" damages for which he was responsible from those "solely incident to the preexisting condition."133

When the preexisting condition is also the result of tortious conduct, ${ }^{134}$ some courts appear even more willing to shift to the defendant the burden of unraveling the various influences. When the defendant's tortious conduct contributes along with the torts of others to produce harm, even though it does not constitute a but-for or substantial-factor cause of the entire harm, the Restatement of Torts may place on the defendant the burden of proving how liability should be apportioned between the loss attributable to his conduct and the harm (presumably including the effects of preexisting conditions) caused solely by the other tortfeasors. ${ }^{135}$ The

132. 66 N.J. 268,330 A.2d 355 (1974).

133. Id. at 273,330 A.2d at 358 . A similar rule was applied in Graham v. Roberts, 441 F.2d 995, 998 n.3 (D.C. Cir. 1970).

Another rationale for shifting the burden of proof to the defendant in these situations has been aptly stated in one famous California case. In Haft v. Lone Palm Hotel, 3 Cal. 3d 756, 478 P.2d 465, 91 Cal. Rptr. 745 (1970), the California Supreme Court noted:

[T] he evidentiary void in the instant action results primarily from defendants' failure to pro-

vide a lifeguard to observe occurrences within the pool area .... The absence of such a

lifeguard in the instant case thus not only stripped decedents of a significant degree of protection to which they were entitled, but also deprived the present plaintiffs of a means of definitively establishing the facts leading to the drownings.

Id. at 771, 478 P.2d at 474-75, 9l Cal. Rptr. at 754-55. The court went on to hold that in the type of circumstances presented, upon proof that the defendant violated a duty to provide a lifeguard, the burden shifted to the defendants. Id. at 772, 478 P.2d at 475 , 91 Cal. Rptr. at 755.

Unlike the preceding cases dealing with partial losses in which some such loss was proved, Haft involved a definitive loss. Most courts, unlike that in Haft, require the plaintiff to establish that the defendant caused a definitive loss or some partial loss before the question of the burden of proof on apportionment is even reached. See notes $45,46 \& 71$ supra (citing cases). Under the suggested approach to chance, however, this threshold requirement would be satisfied by proof that the defendent destroyed a chance of loss avoidance.

134. For other problems involved when the source of the preexisting condition is tortious, see pp. 1362-63 supra.

135. RESTATENENT (SECOND) OF TORTS \& 433B(2) (1965). Some courts have imposed joint and several liability directly rather than by shifting the burden of proof when they have found the harm incapable of apportionment as a matter of law. See note 20 supra. Flatly imposing joint and several liability for the entire harm (rather than shifting the burden of proof) is probably unsound except when the defendant's conduct was a cause of the entire harm and the other forces did not constitute preexisting conditions. See pp. 1359-60 supra.

When a tortious preexisting condition was a cause of the harm that the defendant caused, see W. PROSSER, supra note $3, \S 52$, at 320-21, the defendant should have the benefit of a possible reduction of his liability to the plaintiff to the extent of the harm attributable solely to the preexisting condition (even if the burden of apportionment is shifted to the defendant), and the tortfeasors might be entitled to seck contribution or indemnity inter se for that portion of the loss for which both were responsible. See generally RESTATEMENT (SECOND) OF TORTS $\S$ 886A-886B (1979). A number of courts, however, have refused to classify the tortfeasors as joint tortfeasors in this context and have accordingly disallowed contribution; other courts have held them jointly and severally liable and allowed contribution for the loss for which both were responsible. The situations and approaches have been so diver- 
Restatement is unclear, however, on the extent, if at all, to which the conduct of the tortfeasors must be contemporaneous for the rule shifting the burden of proof to apply. ${ }^{136}$ In most multiple tortfeasor cases in which the courts have shifted the burden, ${ }^{137}$ the injuries occurred almost simultaneously or in rapid succession. ${ }^{138}$ The automobile accident involving a chain collision is the most common example. ${ }^{139}$ The courts are more divided when the accidents do not occur in such limited time frames. ${ }^{140}$ There are indications that the rule gradually is being extended to situations in which injuries occur at somewhat different times. ${ }^{141}$

gent as practically to defy generalization. Joint and several liability and rights to contribution may also arise when the defendant is unable to apportion the harm.

When a tortious preexisting condition was not a cause of the harm that the defendent caused, one of two results ordinarily occurs: first, the defendant might be held liable to the plaintiff for harm the defendant caused in excess of that attributable to the preexisting condition, but would have no right of contribution for that harm, or second, if the burden of apportionment were shifted to him and he was unable to apportion, he would be held jointly and severally liable for the entire harm but with a possible right of (and potential liability for) contribution, or perhaps even indemnity, see, e.g., Borel v. Fibreboard Paper Prod. Corp., 493 F.2d 1076, 1094-96 (5th Cir. 1973), cert. denied, 419 U.S. 869 (1974). See also pp. 1362-63 supra (discussing subsuming injuries). The defendant's right to contribution would depend on whether the prior torffeasor was also a "joint tortfeasor" (that is, was liable for the same harm). See RESTATEMENT (SECOND) OF TORTS § 886A (1979). Whether the prior tortfeasor would be a joint tortfeasor may depend on whether the burden of apportionment was also shifted to (and not satisfied by) him, a point on which the courts have reached differing results. Compare, e.g., Borel v. Fibreboard Paper Prod. Corp., 493 F.2d 1076, 1094-96 (5th Cir. 1973), cert. denied, 419 U.S. 869 (1974) (each torteasor jointly and severally liable for entire harm unless apportionment is proved) with Bruckman v. Pena, 29 Colo. App. 357, 359-62, 487 P.2d 566, 567-68 (1971) (first tortfeasor not liable for subsequent harm and does not have burden of apportioning).

In the multiple tortfeasor context, a defendant may not always ultimately benefit from an apportionment even though it reduces his liability to the plaintiff. Whether he would benefit would depend on the net costs and benefits of apportionment in terms of its reduction of his liability to the plaintiff and on the effect (if any) of an apportionment on the defendant's rights to and liabilities for contribution or indemnity that would have existed in the absence of an apportionment. The potential effects of settlement, release, and satisfaction should also be considered. See RESTATEMENT (SECOND) OF TORTS $\S \S 885-886 \mathrm{~A}(1979)$.

136. See RESTATEMENT (SECOND) OF TORTS § 433B(2) \& Comments c-e (1965).

137. Even when the harm occurs within a limited period of time, courts have sometimes refused to shift the burden. See, e.g., Huddell v. Levin, 537 F.2d 726, 737-39 (3d Cir. 1976) ("crashworthiness" situation, see note 25 supra; assuming arguendo that other force was tortious). The "crashworthiness" cases appear split on the question. See D. NOEL \& J. PHILLIPS, PRODUGTS LIABILITY IN A NUTSHELL 176 (2d ed. 1981).

138. See, e.g., Gutowski v. City of New Britain, 165 Conn. 50, 54-55, 327 A.2d 552, 555 (1973) (alleged assaults by two police officers occurring in same incident).

139. See, e.g., Maddux v. Donaldson, 362 Mich. 425, 434-36, 108 N.W.2d 33, 37-38 (1961); Mathews v. Mills, 288 Minn. 16, 20-23, 178 N.W.2d 841, 844-45 (1970); Hill v. Macomber, 103 N.J. Super. 127, 136-37, 246 A.2d 731, 736-37 (1968).

140. Compare, e.g., Treanor v. B.P.E. Leasing, Inc., 158 N.W.2d 4, 5-7 (Iowa 1968) (joint and several liability imposed unless.damages shown, presumably by defendant, to be reasonably capable of apportionment) with Ryan v. Mackolin, 14 Ohio St. 2d 213, 220-22, 237 N.E.2d 377, 382-83 (1968) (two collisions occurring five months apart; burden of proof remains on plaintiff to apportion responsibility).

141. See, e.g., Borel v. Fibreboard Paper Prod. Corp., 493 F.2d 1076, 1094-96 (5th Cir. 1973), cert. denied, 419 U.S. 869 (1974) (multiple failures to warn of danger of work-related exposure to asbestos); cf. Velsicol Chem. Corp. v. Rowe, 543 S.W.2d 337, 342-43 (Tenn. 1976) (third-party complaint for contribution in nuisance action).

A medical malpractice case that has shifted the burden of proof in this type of situation illustrates 
In evaluating the question of the placement of the burden of proof in the preexisting injury situation, it should be noted that when the all-ornothing view of the loss of a chance is rejected, the effect of the placement of the burden of proof will often be less decisive than under traditional rules. Thus, under the suggested approach to chance, even if the burden of proof remains on the plaintiff he would still be able to recover for the loss of a not-better-than-even chance of loss avoidance.

Assuming proof of a preexisting condition and proof that the defendant caused some harm such as loss of a chance, it seems best to adopt the following approach to the burden of allocating the loss between the tort and the preexisting condition, regardless of the origin of that condition: if the preexisting condition and the effect of the defendant's tortious conduct attach nearly simultaneously or within a relatively short time, the burden of proving the extent to which the preexisting condition reduced the value of the interest in question should be shifted to the defendant. If a defendant seeks to reduce his liability by asserting that part of the harm is not attributable to his tortious conduct, the burden of proving both that the plaintiff's injury is capable of apportionment and what the apportionment should be should rest on the defendant. Under the suggested approach to chance, this requirement would include determining the extent to which the preexisting condition reduced the value of the chance-interest adversely affected by the defendant's tortious conduct.

When a significant time interval separates the attachment of the preexisting condition from the harm inflicted by the defendant, the burden of establishing the extent to which the plaintiff's condition is attributable to a particular defendant's conduct-that is, the value of the interest lost-should remain on the plaintiff, subject to one exception. If the plaintiff can demonstrate that he had no reasonable opportunity separately to

the trend. In Incollingo v. Ewing, $444 \mathrm{~Pa} .263,282$ A.2d 206 (1971), the patient had taken an antibiotic prescribed by her pediatrician and for which prescription refills subsequently were authorized by an osteopath. Subsequently, the patient died of aplastic anemia induced by the drug. Id. at 269-73, 282 A.2d at 210-12. The Supreme Court of Pennsylvania held that there was sufficient evidence to support the jury's verdict of negligence against both the pediatrician and the osteopath. One of the osteopath's arguments was that no causal connection had been established between the doses of the drug that he had authorized and the aplastic anemia. In effect, the osteopath contended that the harm had already been suffered or predestined before the doses of medication he authorized had been administered. In response, the court held that once it was established that the immediate cause of death was drug-induced aplastic anemia, the burden of proof shifted to the defendants to prove which series of doses (or whether both) were the fatal ones. Id. at 284-85, 282 A.2d at 218.

The Incollingo case is complicated by the presence of both causation and valuation questions. If the earlier doses of the antibiotic would have killed the patient at the time that she did in fact die, the osteopath's refills could not have been a cause of death unless they were also substantial factors in producing the death. If the osteopath's refills were also either a but-for or substantial-factor cause, the question of what effect the earlier doses, as a preexisting condition, would have on the osteopath's liability would have to be determined. See notes $25 \& 26$ supra. 
evaluate the injury inflicted by the defendant, ${ }^{142}$ the burden of proving the proper apportionment should be shifted to the defendant, or he should be subject to liability without any reduction in damages for the preexisting condition. Moreover, when the plaintiff can prove that because of the tort it was not reasonably possible to prove that there was an existing chance at the time of the tort, the defendant should bear the burden on that issue as well.

Shifting the burden of proof as suggested above can be justified on several grounds. As a matter of basic fairness, a plaintiff should not be disadvantaged merely because a preexisting condition has complicated the allocation of responsibility. Furthermore, to the extent that the defendant's conduct has denied the plaintiff any reasonable opportunity to assess his prior condition, this inflicted imponderability can be thought of as a form of injury. When a physician fails to diagnose a preexisting disease, the subsequent lack of information from which to assess the patient's preexisting condition may have resulted largely from the misdiagnosis itself. Similarly, the burden should be shifted to the defendant when he actively inflicts an injury that, because of its nature or because it follows so closely on the heels of the materialization of a preexisting condition, makes it infeasible for the plaintiff to assess his preinjury condition.

Shifting the burden of proof is not a completely satisfactory solution as long as an all-or-nothing lottery survives. The shift simply realigns the scales. In the context of preexisting conditions, then, shifting the burden of proof should be viewed as collateral to the task of reforming the definition of the injury to include loss of a chance.

\section{Gausation, Valuation, and Ghance Revisited}

The foregoing discussion has focused on the place of chance in the valuation process and upon alternatives to the all-or-nothing approach to the loss of a chance in that context. Throughout, an assiduous attempt has been made to preserve the distinction between causation and valuation. Rejection of the all-or-nothing approach to valuing the loss of a chance does not necessarily affect the continuing validity of the all-or-nothing rule for the causation inquiry. Thus, while the loss of a not-better-thaneven chance of avoiding some adverse result should be a compensable loss, it still must be established that the defendant caused the destruction of that chance. The all-or-nothing principle would ordinarily still operate in the causation inquiry even if it were abandoned for the purposes of valu-

142. The fact that the plaintiff had an opportunity medically to evaluate his preexisting condition prior to the second injury has apparently influenced some courts against shifting the burden of proof, especially if there was "medical scrutiny" of the preexisting condition. See, e.g., Ryan v. Mackolin, 14 Ohio St. 2d 213, 222, 237 N.E.2d 377, 383 (1968). 
ing a lost chance.

To illustrate, assume that a patient suffering from cancer is killed because a surgical instrument fails due to errors in the manufacturing process. Assume that the chance that the patient would be cured of cancer was only $30 \%$. Under the approach proposed in this article, the loss of that chance would be compensable. But if it did not appear more likely than not that the defendant was the manufacturer of the instrument, the plaintiff would ordinarily be denied recovery for that loss. ${ }^{143}$ In other words, proof of a not-better-than-even chance that the defendant caused the loss of the chance of a cure would not suffice. If, however, the plaintiff proved that the defendant was probably the source of the product and thus the cause of the loss, the plaintiff might recover the value of the loss. Thus, the all-or-nothing idea may continue to be applied to causation even if it is abandoned for the purposes of valuation. Whether the all-ornothing approach should continue for causation is another question. Only a few observations on that question will be offered here.

There are some complex causation questions to which application of the principles for valuing chance proposed in this article seem appealing. Consider a plaintiff who had a pronounced preexisting risk of developing epilepsy and who eventually develops the disease. Assume that prior to the onset of the epilepsy, the plaintiff suffered a tortiously inflicted head injury, unrelated to the preexisting condition, that creates an additional risk of epilepsy. Assume also that when the epilepsy does in fact develop, it appears that it probably would have done so precisely when it did even absent the head injury, and that the head injury probably was not a substantial factor in producing it. The defendant did create a chance of epilepsy, but we know that this probably was not the chance that materialized. The traditional rule would say that he therefore caused no loss since the actual events demonstrated that there probably was no chance of avoiding the epilepsy at the time of the second injury. If, under the suggested approach, a judgment were rendered before the epilepsy materialized, the plaintiff would be compensated for the extent to which the tort, by creating an additional chance of epilepsy, reduced the then-existing chance of avoiding the disease. It may be sensible also to compensate for the chance that it may not have been the preexisting risk that materialized, even if the judgment occurs after onset of the epilepsy, when we are not absolutely certain what role was played by the tortious injury.

Or consider an accident victim who was probably dead on arrival at an

143. When a defect occurs that is common to all similar products throughout the industry, at least one case has applied a modified chance-valuation analysis to the causation question. See Sindell v. Abbot Laboratories, 26 Cal. 3d 588, 607 P.2d 924, 163 Cal. Rptr. 132, cert. denied, 101 S. Ct. 286 (1980) (discussed in note 116 supra). 
emergency room where he was negligently left untended. Conceptually, one might reason under a strict causation analysis that there probably was no chance of survival, and deny recovery. One can argue, however, that the chance that the victim was still alive should be compensated by integrating it (albeit by conjunction) into the computation of the value of the chance that he could have been saved.

There may be other types of situations in which matters of causation arguably should be handled under a probabilistic-percentage valuation, rather than an all-or-nothing approach. ${ }^{144}$ Indeed, one may question the general validity of the preponderance of the evidence rule and its all-ornothing concomitant, and ask whether it should be replaced generally by a more sensitive mechanism such as the approach advocated in this article. In any event, the proposals made here should be read as limited ones and should be evaluated in the context of matters of valuation-the process of determining the value of the destroyed loss. Extension or adaptation of these ideas to fit other problems, such as true causation questions, must await another occasion.

\section{Conclusion}

This essay has attempted to develop an analytical framework within which to address problems of the loss of a chance in the contexts of preexisting conditions and future consequences. ${ }^{145}$ It proposes that the all-or-

144. See, e.g., Twerski, The Use and Abuse of Comparative Negligence in Products Liability, 10 IND. L. REV. 797, 828-29 (1977); note 143 supra.

145. There are other situations involving loss of a chance in which the probability-valuation approach urged here is worth considering. In some situations, the plaintiff may allege that the defendant's negligence failed to prevent the development of a dangerous situation. It may appear that there was only a not-better-than-even chance that the injury would have been averted even with proper preventive measures. Under the traditional view, it would be held that the defendant did not cause the injury because it probably would have occurred anyway. Here again, it must be asked whether a more rational result can be achieved by redefining the nature of the plaintiff's loss. Why not ask what the lost chance of avoiding the ultimate injury was worth? Since the defendant's negligent omission asserted itself before the victim was placed in the position of jeopardy, we technically do not have a preexisting condition situation. Nonetheless, the suggested approach to the loss of a chance could prove useful in this context as well.

The suggested approach to the loss of a chance as a compensable interest may also have potential application in tort litigation not involving personal injury. The legal malpractice case serves as a good example. When a former client seeks to recover against a lawyer for legal malpractice that adversely affected his prospects of success in a lawsuit, for example, many courts hold that it must be established under the appropriate standard of proof that the plaintiff would otherwise have achieved a better result but for his lawyer's malpractice. See R. MALLEN \& V. LEVIT, LEGAL MALPRACTICE $\S \S$ 73, 326-370, 415-417 (1977); Wade, The Attorney's Liability for Negligence, 12 VAND. L. REV. 755, 769-71 (1959); Note, The Standard of Proof of Causation in Legal Malpractice Cases, 63 CORNELL L. REV. 666, 667-72 (1978). Under this rule, failure to prove that the plaintiff's prospects for success in the absence of negligence were better than even would ordinarily result in a denial of relief for the lost litigation opportunity. It is more appropriate to award compensation for the loss of the chance of success at trial. On the complex subject of the measure of damages in legal malpractice generally, see R. MALlen \& V. LEVIT, supra, §§ 131-151. 


\section{Causation and Valuation}

nothing approach to the loss of a chance be abandoned for valuation purposes. In its place a set of rules should be adopted that recognizes the destruction of a chance, including a not-better-than-even chance, of some more favorable outcome as a compensable loss worthy of redress, and that appropriately value such losses to reflect their true nature. 